\title{
ANALISIS PENGARUH KINERJA KEUANGAN PERUSAHAAN TERHADAP PERUBAHAN HARGA SAHAM \\ (Studi Kasus Perusahaan Manufaktur yang terdaftar di Bursa Efek Indonesia)
}

\author{
Oleh \\ Khusnah Herawati \\ Alumni STIE AMA Salatiga \\ Joko Pramono \\ Dosen STIE AMA Salatiga
}

\begin{abstract}
Abstrak
Harga saham merupakan ukuran indeks prestasi perusahaan, yaitu seberapa jauh manajemen telah berhasil mengelola perusahaan atas nama pemegang saham yang dipertanggungjawabkan di dalam laporan keuangan perusahaan. Pasar modal dikatakan efisien secara informasional apabila harga sahamnya mencerminkan semua informasi yang relevan. Penelitian ini dilakukan dengan tujuan untuk mengetahui pengaruh kinerja keuangan Quick Ratio (QR), Total Asset Turnover (TAT), Debt to Equity Ratio (DER, Return on Asset (ROA), dan Price Earning Ratio (PER) secara parsial dan simultan berpengaruh terhadap perubahan harga saham pada perusahaan manufaktur yang terdaftar di BEI periode tahun 2005-2007.

Data yang digunakan adalah data sekunder yang diperoleh dari Indonesian Capital Market Directory (ICMD) tahun 2008. Dengan menggunakan teknik purposive sampling, jumlah sampel yang terpilih sebanyak 42 perusahaan manufaktur. Data di analisis dengan menggunakan persamaan regresi berganda setelah melalui uji asumsi klasik, sehingga diperoleh persamaan $Y=1,832+0,251 X_{1}+0,20 X_{2}+0,316 X_{3}+0424$ $X_{4}+0,220 X_{5}$. Selanjutnya dilakukan uji hipotesis untuk mengetahui pengaruh variabel independen baik secara parsial maupun simultan (bersama-sama) terhadap variabel dependen dengan menggunakan uji $t$ statistik dan uji $F$ statistik.

Hasil dari penelitian menunjukkan bahwa variabel QR, TAT, DER dan PER secara parsial tidak berpengaruh signifikan terhadap perubahan harga saham. Sedangkan variabel ROA secara parsial menunjukkan hasil berpengaruh secara signifikan terhadap perubahan harga saham. Dari pengujian secara simultan diperoleh kesimpulan bahwa variabel QR, TAT, DER, ROA dan PER secara bersama-sama tidak berpengaruh secara signifikan terhadap perubahan harga saham. Pada pengujian koefisien determinasi diperoleh angka koefisien sebesar 0,046. Hal ini menunjukkan bahwa pengaruh variabel QR, TAT, DER, ROA dan PER hanya sebesar 4,6\% terhadap perubahan harga saham sedangkan sisanya sebesar 95,4\% dipengauhi variabel lain diluar model penelitian.
\end{abstract}

Kata kunci : perubahan harga saham, Quick Ratio (QR), Total Asset Turnover (TAT), Debt to Equity Ratio (DER, Return on Asset (ROA), dan Price Earning Ratio (PER).

\section{PENDAHULUAN}

Pasar modal merupakan salah satu sarana yang efektif untuk mempercepat akumulasi dana bagi pembiayaan pembangunan melalui mekanisme pengumpulan dana dari masyarakat dan menyalurkan dana tersebut ke sektor-sektor produktif. Dengan berkembangnya pasar modal, maka alternatif investasi bagi para pemodal kini tidak 
lagi terbatas pada aset riil dan simpanan pada sistem perbankan, melainkan dapat menanamkan dananya di pasar modal, baik dalam bentuk saham, obligasi, maupun sekuritas (aset finansial) lainnya.

Dengan membeli saham, para pemodal berharap untuk menerima dividen (pembagian laba) setiap tahun dan keuntungan (capital gains) pada saat sahamnya dijual kembali. Namun pada saat yang sama, merekapun harus siap menghadapi resiko bila hal sebaliknya terjadi. Dalam berinvestasi di pasar modal tidak saja memerlukan pemikiran yang lebih rumit dan informasi yang lebih kompleks, namun juga menghadapi resiko yang relatif lebih besar bila dibanding dengan bentuk-bentuk simpanan pada sistem perbankan. Oleh karena itu, biasanya return yang diharapkan pada investasi saham relatif lebih besar dibanding tingkat bunga simpanan pada bankbank.

Investasi di pasar modal selain memberikan prospek keuntungan tetapi juga ada resiko kerugian, sehingga untuk melindungi kepentingan Investor, maka hanya perusahaan (perseroan) yang sehat dan memenuhi persyaratan dari Bapepam (Badan Pengawas Pasar Modal) sajalah yang diijinkan menjual sahamnya di pasar modal (go public). Menurut Tandelilin (2001: 45), pasar modal secara umum diartikan sebagai pasar yang memperjualbelikan produk berupa dana yang bersifat abstrak. Bentuk konkritnya yaitu produk yang diperjualbelikan di pasar modal berupa lembar suratsurat berharga di bursa efek. Tujuan utama investor melakukan investasi adalah mendapatkan return yang maksimal. Semakin efisien perusahaan dalam menggunakan aktivanya maka return yang diperoleh akan semakin tinggi bagi investor, karena return merupakan salah satu alat untuk menilai seberapa besar keuntungan suatu saham.

Sebelum investor memutuskan akan menginvestasikan dananya di pasar modal, investor harus melakukan penilaian dengan cermat terhadap emiten. Apabila prospek perusahaan emiten membaik, harga saham tersebut biasanya akan meningkat pula, dan perusahaan akan dapat memenuhi kewajibannya dalam memberikan dividen kepada investor. Investor harus percaya bahwa informasi yang diterimanya adalah informasi yang benar, sistem perdagangan di bursa dapat dipercaya, serta tidak ada pihak lain yang memanipulasi informasi dan perdagangan tersebut. Tanpa keyakinan tersebut, pemodal tentunya tidak akan bersedia membeli sekuritas yang ditawarkan perusahaan atau diperjual-belikan di bursa.

Salah satu faktor yang mendukung kepercayaan pemodal adalah persepsi mereka akan kewajaran harga sekuritas. Harga saham merupakan ukuran indeks prestasi perusahaan, yaitu seberapa jauh manajemen telah berhasil mengelola perusahaan atas nama pemegang saham yang dipertanggungjawabkan di dalam laporan keuangan perusahaan. Pasar modal dikatakan efisien secara informasional apabila harga sahamnya mencerminkan semua informasi yang relevan. Semakin tepat dan cepat informasi sampai kepada calon pemodal dan dicerminkan pada harga saham, maka pasar modal yang bersangkutan semakin efisien. Dalam melakukan analisis keuangan sangat tergantung pada informasi yang diberikan oleh laporan keuangan.

Laporan keuangan mempunyai peranan dalam penyediaan informasi kinerja keuangan perusahaan terutama profitabilitas yang diperlukan untuk menilai perubahan potensial sumber daya ekonomi yang mungkin dikendalikan. Investor dapat menggunakan pendekatan fundamental untuk menilai perusahaan yang dijelaskan oleh rasio keuangan dengan cara membuat dua jenis perbandingan. Pertama, membandingkan rasio keuangan suatu perusahaan dari waktu ke waktu untuk mengamati trend yang terjadi. Kedua, membandingkan rasio keuangan sebuah 
perusahaan dengan perusahaan lain yang masih bergerak dalam industri yang relatif sama pada periode tertentu.

Perusahaan harus mempunyai nilai rasio keuangan yang baik dan dapat menghasilkan laba yang tinggi seperti yang diharapkan oleh para pemegang saham (Hidayat, 2000:73). Secara teoritis, bila rasio keuangan perusahaan baik menunjukkan perbaikan kinerja keuangan perusahaan emiten sehingga harga pasar dari saham tersebut juga akan meningkat. Hal ini akan mengakibatkan harga jual lebih tinggi dibandingkan harga saat pembelian saham sehingga apabila menjualnya akan mendapatkan keuntungan (capital gain). Seorang investor tidak hanya melakukan analisis kesehatan emiten, tetapi juga menilai berapa harga yang pantas untuk saham tersebut guna menghindari pembelian saham yang terlalu mahal (overpriced) sehingga pertimbangan dalam menilai harga saham juga sangat mempengaruhi perilaku investor untuk membeli, mempertahankan, dan menjual saham perusahaan.

Penelitian ini adalah untuk menguji sejauh mana pengaruh kinerja keuangan perusahaan terhadap perubahan harga saham. Kinerja keuangan perusahaan yang akan digunakan dalam penelitian ini, yaitu faktor fundamental perusahaaan seperti Quick Ratio (QR), Total Asset Turnover (TAT), Debt to Equity Ratio (DER, Return on Asset (ROA), dan Price Earning Ratio (PER). Peneliti mengambil sampel perusahaan manufaktur karena sebagian besar perusahaan yang terdaftar di Bursa Efek Indonesia adalah perusahaan yang bergerak dalam sektor manufaktur dan memberikan kontribusi yang besar terhadap perekonomian Indonesia.

\section{Rumusan Masalah}

Berdasarkan latar belakang masalah penelitian diatas, penulis mempunyai rumusan masalah sebagai berikut :

1. Apakah ada pengaruh antara faktor-faktor kinerja keuangan seperti Quick Ratio(QR), Total Assets Turnover (TAT), Debt to Equity Ratio (DER), Return On Asset (ROA), dan Price Earning Ratio (PER) secara parsial dengan perubahan harga saham pada perusahaan manufaktur yang terdaftar di BEI?

2. Apakah faktor-faktor kinerja keuangan seperti Quick Ratio, Total Assets Turnover, Debt to Equity Ratio, Return On Asset, dan Price Earning Ratio berpengaruh secara simultan terhadap perubahan harga saham pada perusahaan manufaktur yang terdaftar di BEI?

\section{Tujuan Penelitian}

Penelitian ini dilakukan dengan tujuan untuk mengetahui :

1. Pengaruh antara faktor-faktor kinerja keuangan seperti Quick Ratio(QR), Total Assets Turnover (TAT), Debt to Equity Ratio (DER), Return On Asset (ROA), dan Price Earning Ratio (PER) secara parsial terhadap perubahan harga saham pada perusahaan manufaktur yang terdaftar di BEI;

2. Pengaruh faktor-faktor kinerja keuangan seperti Quick Ratio, Total Assets Turnover, Debt to Equity Ratio, Return On Asset, dan Price Earning Ratio secara simultan terhadap perubahan harga saham perusahaan manufaktur yang terdaftar di BEI.

\section{Manfaat Penelitian}

Adapun manfaat yang diharapkan dalam penelitian ini adalah:

1. Manfaat Teoritis

a. Untuk menambah pemahaman serta mendukung teori-teori yang berkaitan dengan masalah yang di teliti;

b. Sebagai pelengkap referensi manajemen keuangan; 
c. Sebagai bahan perbandingan dan masukan bagi peneliti lainnya.

2. Manfaat Praktis

a. Memberi masukan tentang pengaruh kinerja keuangan terhadap perubahan harga saham pada manajemen perusahaan, khususnya perusahaan manufaktur yang terdaftar di BEI, sehingga dapat digunakan sebagai bahan pertimbangan untuk pengambilan keputusan di masa yang akan datang;

b. Memberikan informasi dan bahan pertimbangan tentang pengaruh kinerja keuangan terhadap perubahan harga saham bagi investor yang berkepentingan untuk berinvestasi di pasar modal.

\section{LANDASAN TEORI}

\section{Pasar Modal}

Pengertian pasar modal secara umum adalah suatu sistem keuangan yang terorganisasi, termasuk didalamnya adalah bank-bank komersial dan semua lembaga perantara dibidang keuangan, serta keseluruhan surat-surat berharga yang beredar. Dalam arti sempit, pasar modal adalah suatu pasar (tempat, berupa gedung) yang disiapkan guna memperdagangkan saham-saham, obligasi-obligasi, dan jenis surat berharga lainnya dengan memakai jasa para perantara pedagang efek (Sunariyah, 2006 : 4). Dilihat dari pengertian akan pasar modal diatas, maka jelaslah bahwa pasar modal merupakan salah satu cara bagi perusahaan dalam mencari dana dengan menjual hak kepemilikkan perusahaan kepada masyarakat.

Fungsi Pasar Modal sebagai tempat bertemunya pihak yang memiliki dana lebih (lender) dengan pihak yang memerlukan dana jangka panjang tersebut (borrower). Pasar modal mempunyai dua fungsi yaitu ekonomi dan keuangan. Di dalam ekonomi, pasar modal menyediakan fasilitas untuk memindahkan dana dari lender ke borrower. Dengan menginvestasikan dananya lender mengharapkan adanya imbalan atau return dari penyerahan dana tersebut. Sedangkan bagi borrower, adanya dana dari luar dapat digunakan untuk usaha pengembangan usahanya tanpa menunggu dana dari hasil operasi perusahaannya. Di dalam keuangan, dengan cara menyediakan dana yang diperlukan oleh borrower dan para lender tanpa harus terlibat langsung dalam kepemilikan aktiva riil

Seorang investor di pasar modal selalu mengharapkan keuntungan yang diperoleh dari jenis efek yang dipilih pada masa yang akan datang. Sebelum memutuskan untuk bertransaksi di pasar modal, seorang investor perlu mengetahui hal-hal yang berlaku di pasar modal, yaitu :

1) Resiko dan ketidakpastian

Merupakan ketidakpastian yang menyertai seorang investor dalam berinvestasi di pasar modal. Untuk mengatasi masalah ini, investor harus mempunyai pengetahuan tertentu mengenai perkiraan-perkiraan rasional pada masa yang akan datang. Dari perkiraan-perkiraan rasional ini dibuatlah keputusan investasi yang diperkirakan dapat menghasilkan keuntungan yang paling besar dengan resiko yang paling kecil.

2) Determinasi investasi

Merupakan unsur-unsur yang melandasi seorang investor dalam memutuskan memilih suatu jenis investasi. Unsur-unsur tersebut adalah kondisi investor, motif investasi, media investasi, analisis modal dan strategi investasi. 
3) Penaksiran nilai saham

Investor yang melakukan investasi di bursa efek selalu memperhatikan indikatorindikator yang dapat mempengaruhi besar kecilnya keuntungan yang akan diperoleh. Salah satu indikator yang dapat mempengaruhi besar kecilnya keuntungan yang akan diperoleh dari investasi adalah nilai saham.

Dalam konteks teori, ada tiga cara untuk melakukan investasi dalam bentuk saham (Syahib Natarsyah, 2000:12) yaitu :

1) Analisis Fundamentalis

Menyatakan bahwa setiap investasi saham mempunyai landasan yang kuat disebut nilai intrinsik yang dapat ditentukan melalui suatu analisis yang sangat hati-hati terhadap kondisi perusahaan pada saat sekarang dan prospeknya dimasa mendatang. Nilai intrinsik merupakan suatu fungsi dari faktor-faktor perusahaan yang dikombinasikan untuk menghasilkan suatu keuntungan (return) yang diharapkan dengan suatu resiko yang melekat pada saham tersebut.

2) Analisis Teknikal

Suatu teknik analisis dengan menggunakan data atau catatan pasar untuk berusaha mengakses permintaan dan penawaran suatu saham tertentu maupun pasar secara keseluruhan. Analisis teknikal menggunakan data pasar yang dipublikasikan seperti harga saham, volume perdagangan serta faktor-faktor lain yang bersifat teknis. Model analisis teknikal ini lebih menekankan pada tingkah laku pemodal dimasa yang akan datang berdasarkan kebiasaan yang lalu (nilai psikologis).

3) Analisis Portofolio

Salah satu karakteristik investasi pada sekuritas (saham) adalah kemudahan untuk membentuk portofolio investasi. Artinya pemodal dapat dengan mudah menyebar (diversifikasi) investasinya pada berbagai kesempatan. Jadi pembentukan portofolio sebetulnya berangkat dari usaha diversifikasi untuk mengurangi risiko. Portofolio diartikan sebagai serangkaian kombinasi beberapa aktiva yang diinvestasikan dan dipegang oleh investor baik perorangan maupun lembaga.

\section{Harga Saham}

Harga suatu saham mencerminkan sebuah persetujuan atau konsensus, yaitu harga di mana pembeli setuju untuk membelinya dan penjual setuju untuk menjualnya (Salim, 2003:3). Harga di mana investor bersedia untuk membeli atau menjual bergantung pada apa harapannya. Jika dia mengharapkan harga saham naik, dia akan membelinya. Jika dia mengharapkan harga saham akan turun, dia akan menjualnya.

Harga saham dapat ditentukan oleh nilai nilai pasar (NPS) dan nilai intrinsik (NI) saham (Suwardjono, 2006:485), yaitu:

1) Bilai NPS < NI berarti sekuritas dinilai lebih rendah (undervalued) oleh pasar sehingga harus dibeli atau ditahan bila telah dimiliki.

2) Bila NPS > NI berarti sekuritas dinilai lebih tinggi oleh pasar dijual dengan harga yang mahal (overvalued) oleh pasar sehingga harus dihindari, dijual bila telah dimiliki, atau lakukan short sale.

3) Bila NPS = NI berarti sekuritas dinilai benar dan terjadi ekuilibrium pasar.

Faktor-faktor yang Mempengaruhi Harga Saham 
Harga saham di pasar modal (pasar sekunder) setiap saat dapat mengalami perubahan. Usman (1990) dalam Sahetapy (1998) menyatakan bahwa terdapat beberapa faktor yang mempengaruhi harga saham, diantaranya:

1) Faktor Psikologis dari Penjual atau Pembeli

Tindakan secara irrasional berupa tindakan ikut-ikutan akan mempengaruhi harga saham pasar modal.

2) Faktor Kondisi Perusahaan

Misalnya, kemampuan perusahaan dalam menghasilkan laba yang semakin baik. Hal ini akan mengakibatkan minat para investor semakin tinggi terhadap saham yang dikeluarkan.

3) Faktor Kebijaksanaan Direksi

Misalnya, dalam pembagian laba dalam bentuk dividen yang kontinyu dan semakin besar. Hal ini akan menarik bagi investor bermotivasi untuk memperoleh dividen dan lebih lanjut akan mempengaruhi harga saham.

4) Faktor Tingkat Suku Bunga

Dengan tingkat suku bunga deposito yang tinggi, maka investor di pasar modal akan mengalihkan investasi mereka ke dalam bentuk deposito. Hal ini akan mengakibatkan harga saham di pasar modal semakin turun.

5) Faktor Harga Komoditi

Jika harga barang-barang secara umum meningkat, akan menurunkan kemampuan daya beli masyarakat. Demikian juga akan menurunkan daya beli saham di pasar modal. Selanjutnya akan mempengaruhi harga saham di pasar modal.

6) Faktor Kondisi Keuangan

Dengan keadaan ekonomi yang semakin baik, maka kemampuan daya beli masyarakat semakin baik pula. Hal ini turut mempengaruhi daya beli masyarakat terhadap saham-saham yang ditawarkan di pasar modal.

7) Faktor Investasi Lainnya

Bila ada kesempatan mengadakan investasi pada bidang lain yang lebih menguntungkan, maka investor akan mengalihkan dananya ke bidang yang lebih menguntungkan tersebut dan selanjutnya akan mempengaruhi harga saham.

8) Faktor Kebijaksanaan Pemerintah

Misalnya, dalam rangkaian kebijaksanaan deregulasi menyebabkan jumlah perusahaan yang menjual sahamnya melalui pasar modal semakin banyak. Hal ini akan mempengaruhi harga saham di pasar modal.

9) Faktor Inflasi

Semakin tinggi inflasi mengakibatkan daya beli masyarakat semakin menurun. Hal ini akan mempengaruhi daya beli terhadap saham dan selanjutnya akan mempengaruhi harga saham.

10) Faktor Penawaran dan Permintaan Jumlah saham yang ditawarkan dan jumlah saham yang dimintakan mempengaruhi harga saham. 


\section{Analisis Laporan Keuangan}

Dalam melakukan analisis laporan keuangan, para analis membuat suatu tolok ukur. Tolok ukur yang sering digunakan berupa rasio keuangan. Analisis rasio keuangan merupakan metode umum yang digunakan untuk mengukur kinerja perusahaan di bidang keuangan. Rasio merupakan alat yang memperbandingkan suatu hal dengan hal lainnya sehingga dapat menunjukkan hubungan atau korelasi dari suatu laporan finansial berupa neraca dan laporan laba rugi.

Rasio keuangan bukan merupakan kriteria yang mutlak, tetapi rasio keuangan akan bermakna terutama untuk menunjukkan perubahan dalam kondisi keuangan atau prestasi operasi dan membantu menggambarkan tren dan pola perubahan tersebut yang menunjukkan kepada analis risiko dan peluang bagi perusahaan yang sedang diteliti.

Hanafi dan Halim (2005:77) menyatakan bahwa pada dasarnya analisis rasio dapat dikelompokkan ke dalam lima macam kategori, yaitu:

\section{(1) Rasio Likuiditas}

Rasio likuiditas adalah ukuran penilaian kinerja perusahaan yang dimaksudkan untuk mengukur kemampuan perusahaan untuk membayar utangnya (Rudianto, 2006:316). Rasio likuiditas mengukur kemampuan untuk membayar hutang-hutang jangka pendek perusahaan dengan melihat aktiva lancar perusahaan relatif terhadap hutang lancarnya. Rasio likuiditas terdiri dari rasio lancar (current ratio) dan rasio cepat (acid test ratio atau quick ratio).

\section{(2) Rasio Aktivitas}

Rasio aktivitas adalah ukuran penilaian kinerja perusahaan yang dimaksudkan untuk mengukur sampai seberapa besar efektivitas perusahaan dalam menggunakan sumber-sumber dananya (Rudianto, 2006:315). Rasio aktivitas terdiri dari perputaran piutang (account receivables turnover), perputaran persediaan (inventory turnover), perputaran aktiva tetap (fixed assets turnover), dan perputaran total aktiva (total asset turnover).

\section{(3) Rasio Solvabilitas}

Rasio solvabilitas adalah ukuran penilaian kinerja perusahaan yang dimaksudkan untuk mengukur sampai seberapa besar aktiva perusahaan dibiayai dengan utang (Rudianto, 2006:316). Suatu perusahaan yang solvable berarti perusahaan tersebut mempunyai aktiva atau kekayaan yang cukup untuk membayar semua hutang-hutangnya. Rasio solvabilitas terdiri dari total hutang terhadap total aset (debt to total assets ratio), total hutang terhadap total modal sendiri (debt to equity ratio), times interest earned, dan fixed charged coverage.

\section{(4) Rasio Profitabilitas}

Tujuan fundamental perusahaan adalah menghasilkan laba. Rasio profitabilitas merupakan rasio yang melihat kemampuan perusahaan menghasilkan laba di mana mempunyai peranan penting dalam setiap pengambilan keputusan. Rasio profitabilitas adalah ukuran penilaian kinerja perusahaan yang menunjukkan hasil akhir dari sejumlah kebijaksanaan dan keputusan-keputusan yang diambil manajemen perusahaan (Rudianto, 2006:315). Rasio profitabilitas menunjukkan gabungan efek-efek dari likuiditas, manajemen aktiva, dan hutang pada hasil operasi. Rasio profitabilitas terdiri dari profit margin, return on asset, dan return on equity. 


\section{(5) Rasio Pasar}

Rasio pasar melihat perkembangan nilai perusahaan relatif terhadap nilai buku perusahaan. Rasio ini memberikan indikasi kepada manajemen mengenai apa yang dipikirkan oleh para investor tentang kinerja masa lalu dan prospek di masa mendatang. Jika rasio likuiditas, aktivitas, solvabilitas, dan profitabilitas semuanya terlihat baik, maka rasio nilai pasarnya juga akan meningkat dan harga saham kemungkinan juga akan meningkat. Rasio pasar terdiri dari earing per share, price earning ratio, dividen per share, dividend yield, dividen pay-out, dan price to book value.

\section{PENELITIAN TERDAHULU}

Ada beberapa studi dan penelitian yang meneliti pengaruh hubungan beberapa variable dengan return saham. Penelitian tersebut antara lain :

a. Kusumasari (2005) menganalisi pengaruh kinerja keuangan terhadap perubahan harga saham pada 16 perusahaan manufaktur yang terdaftar di BEJ tahun 19992003. Variabel kinerja keuangan yang digunakan dalam penelitian ini adalah net profit margin, return on equity, earning per share, dividend yield, dan debt ratio. Hasil penelitian menunjukkan bahwa kinerja keuangan perusahaan secara bersama-sama mempunyai pengaruh yang signifikan terhadap harga saham, sedangkan variabel kinerja keuangan perusahaan yang paling signifikan terhadap harga saham dalam penelitian tersebut adalah earning per share.

b. Susilawati (2005) menganalisis secara parsial dan secara simultan pengaruh rasio keuangan terhadap harga saham pada 30 perusahaan manufaktur yang terdaftar di BEJ selama periode 1999-2003. Rasio keuangan yang digunakan adalah return on assets, return on equity, price to book value, price earning ratio, net profit margin, dan operating profit margin. Hasil penelitian menunjukkan bahwa rasio keuangan berpengaruh secara signifikan terhadap harga saham, sedangkan variabel independen yang berpengaruh paling signifikan adalah return on equity dan price to book value.

\section{Kerangka Pemikiran}

Kinerja keuangan perusahaan merupakan informasi yang menggambarkan keadaan suatu perusahaan dan faktor-faktor lain yang dapat mempengaruhi kondisi perusahaan tersebut. Faktor kinerja keuangan yang akan digunakan sebagai variable independen dalam mempengaruhi return saham adalah Quick Ratio, Total Assets Turnover, Debt to Equity Ratio, Return On Asset, dan Price Earning Ratio.

Kerangka pemikiran teoritis dalam penelitian ini dapat digambarkan dalam suatu bagan sebagai berikut : 


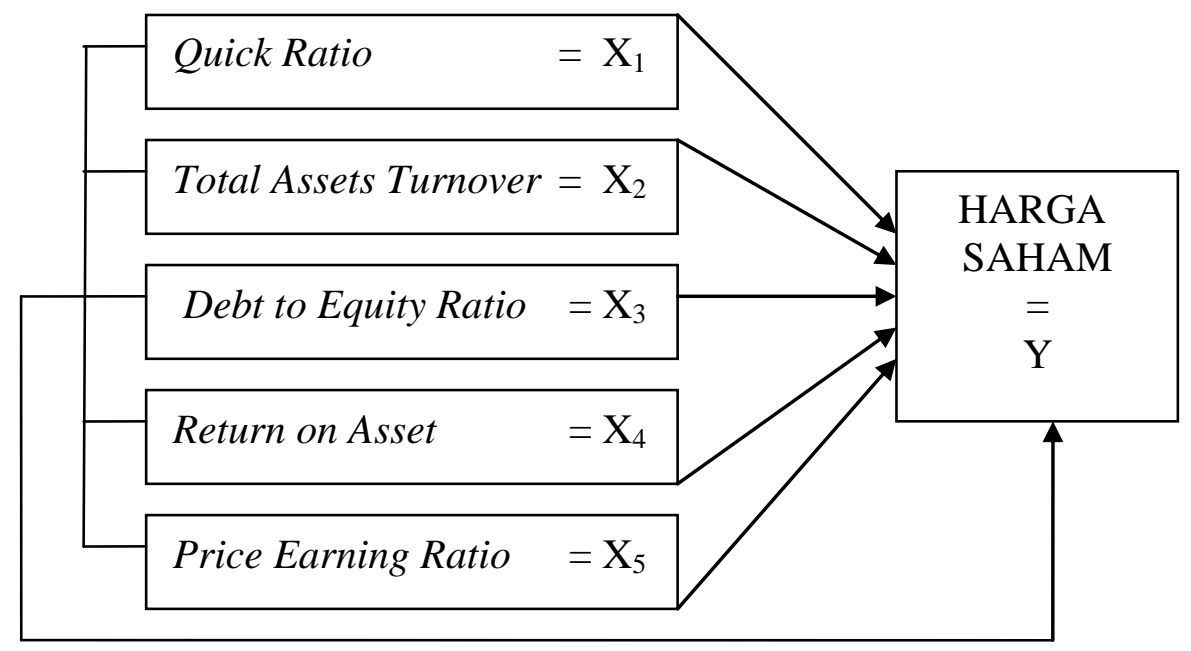

\section{GAMBAR 1 \\ Kerangka Pemikiran}

\section{HIPOTESIS PENELITIAN}

Berdasarkan kerangka pemikiran, maka hipotesis yang diajukan dalam penelitian ini dapat dirumuskan sebagai berikut:

Hipotesis 1, Quick Ratio $(Q R)$, berpengaruh signifikan terhadap perubahan harga saham.

Hipotesis 2, Total Assets Turnover (TAT), berpengaruh signifikan terhadap perubahan harga saham.

Hipotesis 3, Debt to Equity Ratio (DER), berpengaruh signifikan terhadap perubahan harga saham.

Hipotesis 4, Return On Asset (ROA), berpengaruh signifikan terhadap perubahan harga saham.

Hipotesis 5, Price Earning Ratio (PER), berpengaruh signifikan terhadap perubahan harga saham.

Hipotesis 6, Quick Ratio, Total Assets Turnover, Debt to Equity Ratio, Return On Asset, dan Price Earning Ratio secara simultan berpengaruh signifikan terhadap perubahan harga saham.

\section{METODE PENELITIAN}

\section{Tipe Penelitian}

Tipe penelitian yang dilakukan adalah penelitian dengan pendekatan kuantitatif yaitu menekankan analisisnya pada data-data numerikal (angka) yang diolah dengan metode statistik. Dengan metode kuantitatif akan diperoleh signifikasi perbedaan kelompok atau signifikasi hubungan antar variabel yang diteliti (Azwar, 2005:5). Penggunaan tipe penelitian ini disebabkan karena data yang digunakan berupa angkaangka yang terdapat dalam laporan keuangan serta analisis kinerja perusahaan (QR, TAT, DER, ROA dan PER) yang datanya telah tersedia dalam Indonesian Capital Market Directory (ICMD) khususnya perusahaan manufaktur yang terdaftar di Bursa Efek Indonesia.

\section{Populasi dan Sampel}


Populasi adalah keseluruhan subyek penelitian (Arikunto, 2006:130). Populasi yang digunakan dalam penelitian ini adalah seluruh perusahaan manufaktur yang terdaftar di Bursa Efek Indonesia tahun 2004-2007. Alasan memilih perusahaan manufaktur, karena perusahaan manufaktur merupakan penggerak dalam sektor perekonomian di Indonesia

Sampel adalah sebagian atau wakil populasi yang diteliti (Arikunto, 2006:131). Pemilihan sampel yang digunakan dalam penelitian secara purposive sampling, yaitu populasi yang akan dijadikan sampel merupakan populasi yang memenuhi kriteria sampel tertentu sesuai dengan yang dikehendaki oleh peneliti. Adapun beberapa kriteria sampel yang harus dipenuhi dalam penelitian ini sebagai berikut:

1. Seluruh perusahaan manufaktur yang terdaftar di Bursa Efek Indonesia dan tercatat sebagai emiten sejak tahun 2004-2007 secara terus menerus (tidak pernah delisting).

2. Perusahaan manufaktur yang menerbitkan laporan keuangan tahun 2004-2007.

3. Memperoleh laba atau tidak mengalami kerugian tahun 2004-2007.

4. Perusahaan tidak melakukan corporate action seperti pembagian deviden, stock split, waran, merger dan akuisisi selama periode 2004-2007.

Berdasarkan kriteria-kriteria yang sudah ditetapkan maka proses pemilihan sample dilakukan sebagai berikut :

a. Perusahaan manufaktur yang terdaftar di BEI tahun 2007

b. Perusahaan yang tidak mendapatkan laba selama empat tahun berturut-turut (2004-2007)

c. Perusahaan yang mendapatkan laba selama empat tahun berturut-turut (2004-2007)

d. Perusahaan yang melakukan corporate action

e. Jumlah sampel perusahaan yang digunakan

Sehingga diperoleh empat puluh dua perusahaan yang masuk dalam perusahaan manufaktur yang dapat dijadikan sampel penelitian.

\section{Definisi Konsep}

1) Quick Ratio (QR),merupakan rasio likuiditas untuk mengukur kemampuan perusahaan dalam membayar kewajiban yang harus segera dipenuhi dengan aktiva lancar yang lebih likuid (liquid assets).

2) Total Assets Turnover (TAT), menunjukkan tingkat efisiensi penggunaan seluruh aset perusahaan dalam rangka menghasilkan penjualan atau menggambarkan berapa rupiah penjualan bersih yang dapat dihasilkan oleh setiap rupiah yang diinvestasikan dalam bentuk aset perusahaan.

3) Debt to Equity Ratio (DER), mengukur risiko struktur modal dalam hal hubungan antara dana yang dipasok oleh kreditor (hutang) dan investor (ekuitas).

4) Return On Asset (ROA), atau yang biasa dikenal return on investment menunjukkan jumlah laba yang diperoleh secara relatif terhadap tingkat investasi dalam total aset.

5) Price Earning Ratio (PER), menjelaskan harga saham relatif terhadap earning-nya. Perusahaan yang diharapkan akan tumbuh tinggi (mempunyai prospek baik) mempunyai PER yang tinggi, sebaliknya perusahaan yang diharapkan mempunyai pertumbuhan rendah akan mempunyai PER yang rendah.

\section{Definisi Operasional}


Berdasarkan data yang didapat dari penelitian ini, maka indikator yang digunakan adalah sebagai berikut :

1. Perubahan Harga Saham

Merupakan perubahan harga saham yang terjadi di BEI pada saham perusahaan manufaktur. Untuk menghitung perubahan harga saham dalam penelitian ini menggunakan harga penutupan saham pertahun (closing price).

$$
\Delta H S=H S_{t}-H S_{t-1} \times 100 \%
$$

Keterangan:

$\Delta \mathrm{HS}$ : perubahan harga saham

$\mathrm{HS}_{\mathrm{t}}$ : harga saham saat tahun $\mathrm{t}$

$\mathrm{HS}_{\mathrm{t}-1}$ : harga saham saat tahun $\mathrm{t}-1$

2. Quick Ratio $(Q R)$,

Quick ratio merupakan rasio likuiditas untuk mengukur kemampuan perusahaan dalam membayar kewajiban yang harus segera dipenuhi dengan aktiva lancar yang lebih likuid (liquid assets). Rasio ini dapat dirumuskan sebagai berikut :

\section{Quick Ratio $=\underline{\text { Current Assets }- \text { Inventory }}$}

\section{Current Liabilities}

\section{Total Assets Turnover (TAT)}

Total asset turnover menunjukkan tingkat efisiensi penggunaan seluruh aset perusahaan dalam rangka menghasilkan penjualan atau menggambarkan berapa rupiah penjualan bersih yang dapat dihasilkan oleh setiap rupiah yang diinvestasikan dalam bentuk aset perusahaan. Rumus yang digunakan adalah

\section{Total Assets Turnover $=$ Sales Total Assets}

\section{Debt to Equity Ratio (DER)}

Debt to equity ratio mengukur risiko struktur modal dalam hal hubungan antara dana yang dipasok oleh kreditor (hutang) dan investor (ekuitas).

Rasio ini dapat dirumuskan sebagai berikut :

\section{Debt to Equity Ratio $=\quad$ Total Liabilities}

\section{Return On Asset (ROA)}

\section{Total Stockholder's Equity}

ROA atau yang biasa dikenal return on investment menunjukkan jumlah laba yang diperoleh secara relatif terhadap tingkat investasi dalam total aset. Rasio yang digunakan adalah :

\section{Return on Assets $=\underline{\text { Net Income After Tax }}$ \\ Total Assets}

\section{Price Earning Ratio (PER)}

PER menjelaskan harga saham relatif terhadap earning-nya. Perusahaan yang diharapkan akan tumbuh tinggi (mempunyai prospek baik) mempunyai PER yang tinggi, sebaliknya perusahaan yang diharapkan mempunyai pertumbuhan rendah akan mempunyai PER yang rendah. Perhitungan PER dirumuskan sebagai berikut :

\section{Price Earning Ratio $=$ Market_Price Earning per Share}




\section{Jenis dan Sumber Data}

Jenis data yang digunakan dalam penelitian ini adalah data sekunder. Data sekunder merupakan data penelitian yang diperoleh peneliti secara tidak langsung melalui media perantara (Indriantoro dan Supomo, 2002:147). Sumber data sekunder penelitian ini yaitu berupa Laporan Keuangan Auditan pada perusahaan manufaktur yang go public di Bursa Efek Indonesia tahun 2004-2007 yang diperoleh dari Indonesian Capital Market Directory (ICMD) tahun 2008.

\section{Metode Analisis Data}

Analisis Rasio Keuangan

a. Rasio Likuiditas

Dalam penelitian ini, penulis akan menggunakan quick ratio $(\mathrm{QR})$, yang dinyatakan dengan rumus:

\section{Quick Ratio $=\underline{\text { Current Assets }- \text { Inventory }}$} Current Liabilities

\section{b. Rasio Aktivitas}

Dalam penelitian ini, penulis akan menggunakan total asset turnover ratio (TAT), yang dinyatakan dengan rumus:

\section{c. Rasio Solvabilitas}

$$
\text { Total Assets Turnover }=\frac{\text { Sales }}{\text { Total Assets }}
$$

Dalam penelitian ini, penulis akan menggunakan debt to equity ratio (DER), yang dinyatakan dengan rumus:

\section{Debt to Equity Ratio $=\quad$ Total Liabilities \\ Total Stockholder's Equity}

\section{d. Rasio Profitabilitas}

Dalam penelitian ini, penulis akan menggunakan return on assets ratio (ROA), yang dinyatakan dengan rumus:

\section{Return on Assets = Net Income After Tax}

Total Assets

\section{e. Rasio Pasar}

Dalam penelitian ini, penulis akan menggunakan price earning ratio (PER), yang dinyatakan dengan rumus:

$$
\text { Price Earning Ratio }=\frac{\text { Market Price }}{\text { Earning per Share }}
$$

\section{Uji Asumsi Klasik}

Sebelum melakukan pengujian untuk mendapatkan model regresi yang baik, maka terlebih dahulu dilakukan pengujian asumsi klasik. Suatu model dikatakan baik untuk alat prediksi jika mempunyai best linier unbiased estimator (Gujarati, 1997:39). Selain itu suatu model dikatakan cukup baik dan dapat digunakan untuk memprediksi apabila sudah lolos serangkaian uji asumsi yang melandasinya. Uji asumsi klasik digunakan untuk mengetahui kondisi data yang ada agar dapat menentukan model analisis yang paling tepat digunakan. Untuk dapat memenuhi syarat pengujian regresi maka dilakukan uji asumsi klasik sebagai berikut : 
a. Uji Normalitas

Uji normalitas dilakukan untuk mengetahui distribusi data dalam variabel yang akan digunakan dalam penelitian. Data yang baik dan layak digunakan dalam penelitian adalah data yang memiliki distribusi normal. Untuk menguji normalitas data, dalam penelitian ini dilakukan dengan Normal P-P Plot of Regression Standardized Residual. Deteksi dengan melihat penyebaran data (titik) pada sumbu diagonal dari grafik dengan dasar pengambilan keputusan:

1) Jika data menyebar di sekitar garis diagonal dan mengikuti arah garis diagonal, maka model regresi memenuhi asumsi normalitas.

2) Jika data menyebar jauh dari garis diagonal dan tidak mengikuti arah garis diagonal, maka model regresi tidak memenuhi asumsi normalitas.

b. Uji Heteroskedastisitas

Heteroskedastisitas merupakan bentuk penyimpangan asumsi dalam regresi yang ditandai dengan tidak terpenuhinya asumsi mengenai varian dari setiap kesalahan pengganggu untuk variabel-variabel bebas yang diketahui, merupakan suatu bilangan konstan. Adanya heteroskedastisitas akan mengakibatkan kecenderungan semakin membesarnya varian sehingga uji hipotesis yang dilakukan juga tidak akan memberikan hasil yang valid (Firdaus, 2004:107).

Untuk menguji ada tidaknya heteroskedastisitas, dalam penelitian ini digunakan model chart (diagram scatterplot) dengan asumsi bahwa:

1) Jika pola tertentu seperti titik-titik yang ada membentuk pola tertentu yang beraturan (bergelombang, melebar, kemudian menyempit), maka terjadi heteroskedastisitas.

2) Jika tidak membentuk pola yang jelas serta titik-titik yang menyebar secara acak di atas dan di bawah angka 0 pada sumbu Y, maka tidak terjadi heteroskedastisitas.

c. Uji Multikolinearitas

Multikolinearitas merupakan bentuk penyimpangan asumsi dalam regresi yang ditandai dengan adanya lebih dari satu hubungan linear yang sempurna di antara variabel-variabel bebas dalam model regresi. Apabila terjadi kolinearitas sempurna, maka koefisien regresi dari variabel $\mathrm{X}$ tidak dapat ditentukan serta standard errornya tak terhingga (Firdaus, 2004:111-112). Uji multikolinearitas dalam penelitian ini dilakukan dengan melihat tolerance value atau Variance Inflation Factor (VIF) dari masing-masing variabel indepenen. Batas dari tolerance value adalah 0,1 dan batas VIF adalah 10. Jika tolerance value di bawah 0,1 atau nilai VIF di atas 10 , maka terjadi multikolinearitas.

\section{Analisis Regresi Berganda}

Pengujian ini dilakukan untuk mengetahui besarnya pengaruh variabel independen

(QR, TAT, DER, ROA, dan PER) terhadap variabel dependen (perubahan harga saham).

Model regresi linear berganda dituliskan di bawah ini:

$\mathbf{Y}=\alpha+\beta_{1} \mathbf{X}_{1}+\beta_{2} \mathbf{X}_{2}+\beta_{3} \mathbf{X}_{3}+\boldsymbol{\beta}_{4} \mathbf{X}_{4}+\boldsymbol{\beta}_{5} \mathbf{X}_{5}+e$

Keterangan :

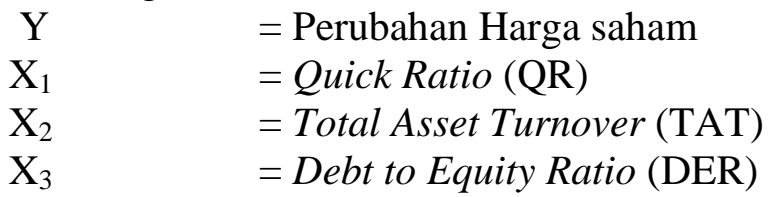




$$
\begin{array}{ll}
\mathrm{X}_{4} & =\text { Return on Asset }(\mathrm{ROA}) \\
\mathrm{X}_{5} & =\text { Price Earning Ratio }(\mathrm{PER}) \\
\alpha & =\text { Konstanta (intercept) } \\
\beta_{1}, \beta_{2}, \beta_{3}, \beta_{4}, \beta_{5} & =\text { Koefisien variabel independen } \\
\mathrm{e} & =\text { standard error }
\end{array}
$$

\section{Pengujian Hipotesis}

Pengujian hipotesis dalam penelitian ini menggunakan pengujian secara parsial (uji t) dan pengujian simultan (uji F).

\section{Koefisien Determinasi $\left(\mathbf{R}^{2}\right)$}

Koefisien determinasi digunakan untuk mengukur seberapa jauh kemampuan model dalam menerangkan variasi-variabel terikat. Nilai koefisien dererminasi antara nol atau satu. Nilai $\mathrm{R}^{2}$ yang kecil berarti kemampuan variabel bebas dalam menjelaskan variasi variabel terikat sangat terbatas. Nilai yang mendekati satu variabel bebas memberikan hampir semua informasi untuk memprediksi variabel terikat.

\begin{tabular}{|c|c|c|}
\hline No & Emiten & Kode \\
\hline 1 & PT Alumindo Light Metal Industry Tbk & ALMI \\
\hline 2 & PT Aqua Golden Mississippi Tbk & AQUA \\
\hline 3 & PT Argha Karya Prima Tbk & AKPI \\
\hline 4 & PT Astra Graphia Tbk & ASGR \\
\hline 5 & PT Bentoel International Investama Tbk & RMBA \\
\hline 6 & PT Betonjaya Manunggal Tbk & BTON \\
\hline 7 & PT Branta Mulia Tbk & BRAM \\
\hline 8 & PT Bristol-Myers Squibb Indonesia Tbk & SQBI \\
\hline 9 & PT Citra Tubindo Tbk & CTBN \\
\hline 10 & PT Darya Varia Laboratoria Tbk & DVLA \\
\hline 11 & PT Delta Djakarta Tbk & DLTA \\
\hline 12 & PT Fajar Surya Wisesa Tbk & FASW \\
\hline 13 & PT Fast Food Indonesia Tbk & FAST \\
\hline 14 & PT Gajah Tunggal Tbk & GJTL \\
\hline 15 & PT Gudang Garam Tbk & GGRM \\
\hline 16 & PT Indocement Tunggal Prakarsa Tbk & INTP \\
\hline 17 & PT Indofarma Tbk & INAF \\
\hline 18 & PT Indofood Sukses Makmur Tbk & INDF \\
\hline 19 & PT Indorama Synthetics Tbk & INDR \\
\hline 20 & PT Jaya Pari Steel Tbk & JPRS \\
\hline 21 & PT Kageo Igar Jaya Tbk (d/h PT Vander Horst Indonesia Tbk) & IGAR \\
\hline 22 & PT Kimia Farma (Persero) Tbk & KAEF \\
\hline 23 & PT Lautan Luas Tbk & LTLS \\
\hline 24 & PT Lionmesh Prima Tbk & LMSH \\
\hline 25 & PT Lion Metal Works Tbk & LION \\
\hline 26 & PT Mayora Indah Tbk & MYOR \\
\hline 27 & PT Merck Tbk & MERK \\
\hline 28 & PT Multi Bintang Indonesia Tbk & MLBI \\
\hline
\end{tabular}

\section{PEMBAHASAN}

Adapun data-data perusahaan manufaktur secara lengkap tersaji sebagai berikut

TABEL 1

Daftar Perusahaan Manufaktur Tahun 2005-2007 


\begin{tabular}{|r|l|c|}
\hline 29 & PT Mustika Ratu Tbk & MRAT \\
\hline 30 & PT Pyridam Farma Tbk & PYFA \\
\hline 31 & PT Roda Vivatex Tbk & RDTX \\
\hline 32 & PT Selamat Sempurna Tbk & SMSM \\
\hline 33 & PT Sepatu Bata Tbk & BATA \\
\hline 34 & PT Siantar Top Tbk & STTP \\
\hline 35 & PT Siwani Makmur Tbk & SIMA \\
\hline 36 & PT Sumi Indo Kabel Tbk (d/h PT IKI Indah Kabel Indonesia Tbk) & IKBI \\
\hline 37 & PT Surya Toto Indonesia Tbk & STI \\
\hline 38 & PT Tiga Pilar Sejahtera Tbk & AISA \\
\hline 39 & PT Trias Sentosa Tbk & TRST \\
\hline 40 & PT Tunas Ridean Tbk & TURI \\
\hline 41 & PT Unggul Indah Cahaya Tbk & UNIC \\
\hline 42 & PT Unilever Indonesia Tbk & UNVR \\
\hline
\end{tabular}

Sumber: Indonesia Capital Market Directory 2008

Dari 42 perusahaan manufaktur yang diobservasi dalam penelitian ini, selama tiga tahun periode penelitian (2005 s/d 2007), maka didapat 126 sampel. Berdasarkan sampel tersebut didapat data angka yang ekstrim, untuk itu dilakukan perhitungan terhadap data ekstrim tersebut dengan $\log \mathrm{N}$ (Log Netral). Mengingat data perubahan harga saham diperoleh beberapa angka negatif, maka setelah di log $\mathrm{N}$ diperoleh sampel sebanyak 85 anggota sampel yang dapat dianalis, seperti data yang dapat dijelaskan dalam tabel berikut :

TABEL 2

Data Sampel yang digunakan untuk analisis statistik (Data Transformasi)

\begin{tabular}{|c|c|c|c|c|c|c|c|}
\hline \multirow{3}{*}{ No. } & \multirow{3}{*}{ Inisial } & QR (X) & TAT (X) & $\operatorname{DER}(\mathrm{X})$ & ROA (\%) & PER (X) & \multirow{3}{*}{$\begin{array}{c}\text { Perubahan } \\
\text { Harga } \\
\text { Saham }\end{array}$} \\
\hline & & Rasio & Rasio & Rasio & Rasio & Rasio & \\
\hline & & Likuiditas & Aktivitas & Solvabilitas & Profitabilitas & Pasar & \\
\hline 1 & AQUA & 1.90 & 0.76 & -0.25 & 2.17 & 2.56 & 3.44 \\
\hline 2 & AKPI & -0.04 & -0.33 & 0.34 & -0.26 & 3.45 & 2.74 \\
\hline 3 & RMBA & 0.22 & 0.17 & -0.43 & 1.77 & 2.13 & 3.12 \\
\hline 4 & BTON & 1.32 & 0.67 & -2.12 & 1.84 & 3.02 & 0.94 \\
\hline 5 & CTBN & 0.27 & 0.12 & -0.36 & 1.93 & 2.22 & 1.83 \\
\hline 6 & DVLA & 1.06 & -0.02 & -0.89 & 2.56 & 1.77 & 1.97 \\
\hline 7 & DLTA & 1.18 & -0.22 & -1.14 & 2.35 & 2.32 & 5.00 \\
\hline 8 & FASW & -0.08 & -0.65 & 0.52 & -1.61 & 6.05 & 1.66 \\
\hline 9 & FAST & -0.19 & 1.00 & -0.42 & 2.39 & 2.56 & 2.66 \\
\hline 10 & INTP & 0.37 & -0.63 & -0.14 & 1.95 & 2.87 & 2.74 \\
\hline 11 & INDF & -0.15 & 0.24 & 0.85 & -0.17 & 4.24 & 2.62 \\
\hline 12 & LTLS & -0.29 & 0.30 & 0.74 & 1.18 & 1.97 & 3.39 \\
\hline 13 & LION & 1.25 & -0.25 & -1.47 & 2.44 & 1.70 & 2.87 \\
\hline 14 & LMSH & 0.03 & 0.90 & -0.01 & 2.28 & 1.49 & 3.20 \\
\hline 15 & MERK & 1.02 & 0.57 & -1.56 & 3.28 & 2.24 & 1.88 \\
\hline 16 & MLBI & -0.80 & 0.39 & 0.42 & 2.72 & 2.49 & 2.87 \\
\hline 17 & RDTX & -0.45 & -0.84 & -1.43 & 1.76 & 2.36 & -0.50 \\
\hline 18 & SMSM & 0.11 & 0.26 & -0.60 & 2.29 & 1.80 & 1.64 \\
\hline 19 & BATA & -0.26 & 0.35 & -0.31 & 2.10 & 2.02 & 1.27 \\
\hline 20 & AISA & -0.65 & -0.17 & 1.02 & -4.61 & 8.78 & 0.87 \\
\hline 21 & TURI & 0.01 & 0.43 & 1.24 & 1.56 & 1.91 & 0.80 \\
\hline 22 & UNIC & -0.09 & 0.09 & 0.20 & 0.59 & 3.12 & 2.63 \\
\hline 23 & UNVCR & -0.17 & 0.96 & -0.27 & 3.62 & 3.12 & 3.39 \\
\hline 24 & BRAM & 0.48 & 0.03 & -0.14 & 1.94 & 1.26 & 2.86 \\
\hline
\end{tabular}




\begin{tabular}{|r|c|r|r|r|r|r|r|}
25 & ALMI & -0.71 & 0.46 & 0.55 & 1.90 & 1.16 & 5.05 \\
\hline 26 & AQUA & 1.93 & 0.75 & -0.26 & 1.81 & 3.39 & 4.31 \\
\hline 27 & ASGR & 0.59 & 0.06 & -0.02 & 2.25 & 2.00 & 1.22 \\
\hline 28 & RMBA & -0.21 & 0.25 & -0.03 & 1.82 & 2.66 & 4.86 \\
\hline 29 & SQBI & 0.68 & 0.16 & -0.53 & 3.04 & 2.51 & 6.06 \\
\hline 30 & CTBN & -0.08 & 0.44 & 0.12 & 2.59 & 1.86 & 4.61 \\
\hline 31 & DVLA & 1.37 & 0.03 & -1.05 & 2.24 & 2.78 & 4.62 \\
\hline 32 & FASW & -0.19 & -0.71 & 0.65 & 1.09 & 3.33 & 2.71 \\
\hline 33 & FAST & -0.27 & 0.97 & -0.39 & 2.66 & 2.47 & 3.94 \\
\hline 34 & GJTL & 0.09 & -0.29 & 0.88 & 0.49 & 2.74 & 1.27 \\
\hline 35 & INTP & -0.03 & -0.42 & -0.53 & 1.82 & 3.58 & 4.13 \\
\hline 36 & INDF & -0.34 & 0.30 & 0.74 & 1.40 & 2.96 & 3.88 \\
\hline 37 & INDR & -0.21 & -0.24 & 0.41 & -1.08 & 2.84 & 0.76 \\
\hline 38 & JPRS & 3.23 & 0.59 & -2.81 & 2.65 & 3.80 & 4.59 \\
\hline 39 & KAEF & 0.41 & 0.55 & -0.80 & 1.25 & 3.04 & 2.62 \\
\hline 40 & LION & 1.33 & -0.27 & -1.39 & 2.40 & 1.71 & 2.30 \\
\hline 41 & MYOR & 1.02 & 0.24 & -0.54 & 1.80 & 2.59 & 4.58 \\
\hline 42 & MERK & 1.35 & 0.54 & -1.61 & 3.42 & 2.34 & 4.17 \\
\hline 43 & MLBI & -1.11 & 0.38 & 0.73 & 2.49 & 2.76 & 2.30 \\
\hline 44 & MRAT & 2.00 & -0.25 & -2.30 & 1.14 & 2.71 & 2.92 \\
\hline
\end{tabular}

Sumber : Data Sekunder (diolah)

TABEL 3

Data Sampel yang digunakan untuk analisis statistik (lanjutan )

\begin{tabular}{|c|c|c|c|c|c|c|c|}
\hline \multirow{3}{*}{ No. } & \multirow{3}{*}{ Inisial } & QR (X) & TAT $(X)$ & DER $(X)$ & ROA (\%) & PER (X) & \multirow{3}{*}{$\begin{array}{c}\text { Perubahan } \\
\text { Harga } \\
\text { Saham }\end{array}$} \\
\hline & & Rasio & Rasio & Rasio & Rasio & Rasio & \\
\hline & & Likuiditas & Aktivitas & Solvabilitas & Profitabilitas & Pasar & \\
\hline 45 & PYFA & 0.03 & -0.30 & -1.31 & 0.73 & 2.74 & 2.41 \\
\hline 46 & RDTX & -0.62 & -1.35 & -0.56 & 1.87 & 2.00 & 2.75 \\
\hline 47 & SMSM & 0.09 & 0.21 & -0.63 & 2.22 & 2.03 & 2.69 \\
\hline 48 & $\begin{array}{l}\text { STTP } \\
\end{array}$ & 0.41 & 0.17 & -1.02 & 1.13 & 2.95 & 3.69 \\
\hline 49 & SIMA & 0.64 & 0.29 & -0.56 & 0.46 & 2.70 & 1.80 \\
\hline 50 & IKBI & 0.28 & 1.18 & -0.54 & 2.02 & 1.73 & 4.51 \\
\hline 51 & STI & -0.30 & -0.09 & 0.81 & 2.17 & 1.41 & 2.30 \\
\hline 52 & TURI & 0.03 & 0.31 & 1.18 & -0.25 & 3.80 & 1.06 \\
\hline 53 & UNVCR & -0.12 & 0.90 & -0.05 & 3.62 & 3.38 & 4.00 \\
\hline 54 & BRAM & 0.83 & -0.01 & -0.49 & 0.18 & 3.84 & 4.63 \\
\hline 55 & ALMI & -0.78 & 0.52 & 0.73 & 0.84 & 2.22 & 2.35 \\
\hline 56 & AQUA & 1.91 & 0.78 & -0.30 & 2.00 & 3.25 & 2.88 \\
\hline 57 & ASGR & -0.08 & 0.15 & -0.01 & 2.45 & 2.40 & 4.54 \\
\hline 58 & RMBA & 0.20 & 0.17 & 0.41 & 1.84 & 2.74 & 4.39 \\
\hline 59 & CTBN & 0.19 & 0.49 & -0.14 & 2.62 & 2.39 & 4.34 \\
\hline 60 & DVLA & 1.50 & -0.09 & -1.56 & 2.19 & 2.89 & 1.79 \\
\hline 61 & FASW & 0.17 & -0.36 & 0.65 & 1.18 & 3.59 & 4.00 \\
\hline 62 & FAST & -0.01 & 0.93 & -0.40 & 2.79 & 2.37 & 3.54 \\
\hline 63 & INTP & 0.50 & -0.31 & -0.82 & 2.28 & 3.43 & 3.75 \\
\hline 64 & INAF & 0.01 & 0.23 & 0.90 & 0.10 & 4.05 & 4.65 \\
\hline 65 & INDF & -0.53 & -0.06 & 0.96 & 1.20 & 3.21 & 4.51 \\
\hline 66 & INDR & -0.26 & -0.21 & 0.48 & -0.99 & 3.12 & 3.95 \\
\hline 67 & IGAR & 0.79 & 0.35 & -0.63 & 1.54 & 2.09 & 3.23 \\
\hline 68 & KAEF & 0.31 & 0.54 & -0.63 & 1.32 & 3.48 & 4.44 \\
\hline
\end{tabular}




\begin{tabular}{|r|c|r|r|r|r|r|r|}
\hline 69 & LTLS & -0.62 & 0.24 & 0.88 & 1.21 & 1.57 & 2.16 \\
\hline 70 & LMSH & -0.19 & 0.63 & 0.15 & 2.25 & 1.22 & 3.16 \\
\hline 71 & MYOR & 0.78 & 0.40 & -0.31 & 2.01 & 2.25 & 2.08 \\
\hline 72 & MERK & 1.48 & 0.50 & -1.71 & 3.30 & 2.58 & 3.44 \\
\hline 73 & PYFA & -0.08 & -0.09 & -0.87 & 0.60 & 3.21 & 4.13 \\
\hline 74 & RDTX & -0.56 & -1.43 & -0.58 & 1.79 & 2.31 & 3.60 \\
\hline 75 & SMSM & -0.19 & 0.25 & -0.42 & 2.27 & 2.04 & 3.13 \\
\hline 76 & BATA & 0.07 & 0.40 & -0.51 & 2.34 & 2.16 & 4.16 \\
\hline 77 & STTP & -0.22 & 0.15 & -0.82 & 1.10 & 3.44 & 4.33 \\
\hline 79 & IKBI & 0.86 & 0.99 & -1.08 & 2.58 & 1.51 & 3.69 \\
\hline 80 & STI & -0.31 & -0.02 & 0.63 & 1.82 & 1.95 & 3.05 \\
\hline 81 & AISA & -0.94 & -0.03 & 1.29 & 1.12 & 3.91 & 5.79 \\
\hline 82 & TRST & -0.48 & -0.36 & 0.17 & -0.19 & 3.32 & 3.00 \\
\hline 83 & TURI & 0.04 & 0.28 & 1.07 & 1.74 & 2.21 & 4.31 \\
\hline 84 & UNIC & -0.60 & 0.13 & 0.12 & 0.24 & 3.48 & 1.01 \\
\hline 85 & UNVCR & -0.27 & 0.85 & -0.02 & 3.61 & 3.27 & 0.82 \\
\hline
\end{tabular}

Sumber : Data Sekunder (diolah)

\section{Data Variabel Dependen}

Variabel dependen dalam penelitian ini adalah perubahan harga saham. Perhitungan perubahan harga saham sebagai variabel dependen (Y) yaitu sebagai berikut :

$$
\Delta \mathrm{HS}=\frac{H S_{t}-H S_{t-1}}{H S_{t-1}} \times 100 \%
$$

Berdasarkan perhitungan perubahan harga saham pada perusahaan manufaktur tahun 2004, 2005, 2006, dan 2007 dapat dilihat pada tabel 5

TABEL 4

Perubahan Harga Saham Tahun 2005-2007 (dalam Rupiah)

\begin{tabular}{|r|c|r|r|r|r|r|r|r|}
\hline \multirow{2}{*}{ No } & \multirow{2}{*}{ Kode } & \multicolumn{4}{|c|}{ Closing Price } & \multicolumn{3}{|c|}{$\Delta$ Closing Price } \\
\cline { 3 - 9 } & & $\mathbf{2 0 0 4}$ & $\mathbf{2 0 0 5}$ & $\mathbf{2 0 0 6}$ & $\mathbf{2 0 0 7}$ & $\mathbf{2 0 0 5 / 2 0 0 4}$ & $\mathbf{2 0 0 6 / 2 0 0 5}$ & $\mathbf{2 0 0 7 / 2 0 0 6}$ \\
\hline 1 & (ALMI) & 445 & 335 & 860 & 950 & $-24,72$ & 156,72 & 10,47 \\
\hline 2 & (AQUA) & 48.000 & 63.000 & 110.000 & 129.500 & 31,25 & 74,60 & 17,73 \\
\hline 3 & (AKPI) & 450 & 520 & 500 & 460 & 15,56 & $-3,85$ & $-8,00$ \\
\hline 4 & (ASGR) & 320 & 295 & 305 & 590 & $-7,81$ & 3,39 & 93,44 \\
\hline 5 & (RMBA) & 110 & 135 & 310 & 560 & 22,73 & 129,63 & 80,65 \\
\hline 6 & (BTON) & 195 & 200 & 200 & 185 & 2,56 & 0,00 & $-7,50$ \\
\hline 7 & (BRAM) & 800 & 940 & 1.900 & 1.900 & 17,50 & 102,13 & 0,00 \\
\hline 8 & (SQBI) & 35.000 & 10.500 & 55.500 & 10.500 & $-70,00$ & 428,57 & $-81,08$ \\
\hline 9 & (CTBN) & 8.000 & 8.500 & 17.000 & 30.000 & 6,25 & 100,00 & 76,47 \\
\hline 10 & (DVLA) & 700 & 750 & 1.510 & 1.600 & 7,14 & 101,33 & 5,96 \\
\hline 11 & (DLTA) & 14.500 & 36.000 & 22.800 & 16.000 & 148,28 & $-36,67$ & $-29,82$ \\
\hline 12 & (FASW) & 950 & 1.000 & 1.150 & 1.780 & 5,26 & 15,00 & 54,78 \\
\hline 13 & (FAST) & 1.050 & 1.200 & 1.820 & 2.450 & 14,29 & 51,67 & 34,62 \\
\hline 14 & (GJTL) & 650 & 560 & 580 & 490 & $-13,85$ & 3,57 & $-15,52$ \\
\hline 15 & (GGRM) & 13.550 & 11.650 & 10.200 & 8.500 & $-14,02$ & $-12,45$ & $-16,67$ \\
\hline 16 & (INTP) & 3.075 & 3.550 & 5.750 & 8.200 & 15,45 & 61,97 & 42,61 \\
\hline
\end{tabular}




\begin{tabular}{|c|c|c|c|c|c|c|c|c|}
\hline 17 & (INAF) & 170 & 115 & 100 & 205 & $-32,35$ & $-13,04$ & 105,00 \\
\hline 18 & (INDF) & 800 & 910 & 1.350 & 2.575 & 13,75 & 48,35 & 90,74 \\
\hline 19 & (INDR) & 625 & 470 & 480 & 730 & $-24,80$ & 2,13 & 52,08 \\
\hline 20 & (JPRS) & 900 & 800 & 1.590 & 355 & $-11,11$ & 98,75 & $-77,67$ \\
\hline 21 & (IGAR) & 105 & 105 & 95 & 119 & 0,00 & $-9,52$ & 25,26 \\
\hline 22 & (KAEF) & 205 & 145 & 165 & 305 & $-29,27$ & 13,79 & 84,85 \\
\hline 23 & (LTLS) & 370 & 480 & 405 & 440 & 29,73 & $-15,63$ & 8,64 \\
\hline 24 & (LMSH) & 1.525 & 1.900 & 1.700 & 2.100 & 24,59 & $-10,53$ & 23,53 \\
\hline 25 & (LION) & 1.700 & 2.000 & 2.200 & 2.100 & 17,65 & 10,00 & $-4,55$ \\
\hline 26 & (MYOR) & 1.200 & 820 & 1.620 & 1.750 & $-31,67$ & 97,56 & 8,02 \\
\hline 27 & (MERK) & 22.800 & 24.300 & 40.000 & 52.500 & 6,58 & 64,61 & 31,25 \\
\hline 28 & (MLBI) & 42.500 & 50.000 & 55.000 & 55.000 & 17,65 & 10,00 & 0,00 \\
\hline 29 & (MRAT) & 410 & 270 & 320 & 295 & $-34,15$ & 18,52 & $-7,81$ \\
\hline 30 & (PYFA) & 60 & 45 & 50 & 81 & $-25,00$ & 11,11 & 62,00 \\
\hline 31 & (RDTX) & 825 & 830 & 960 & 1.310 & 0,61 & 15,66 & 36,46 \\
\hline 32 & (SMSM) & 290 & 305 & 350 & 430 & 5,17 & 14,75 & 22,86 \\
\hline 33 & (BATA) & 14.000 & 14.500 & 14.000 & 23.000 & 3,57 & $-3,45$ & 64,29 \\
\hline 34 & (STTP) & 180 & 150 & 210 & 370 & $-16,67$ & 40,00 & 76,19 \\
\hline 35 & (SIMA) & 265 & 165 & 175 & 220 & $-37,74$ & 6,06 & 25,71 \\
\hline 36 & (IKBI) & 575 & 430 & 820 & 1.150 & $-25,22$ & 90,70 & 40,24 \\
\hline 37 & $(\mathrm{STI})$ & 6.000 & 6.000 & 6.600 & 8.000 & 0,00 & 10,00 & 21,21 \\
\hline 38 & (AISA) & 210 & 215 & 175 & 750 & 2,38 & $-18,60$ & 328,57 \\
\hline 39 & (TRST) & 205 & 150 & 145 & 174 & $-26,83$ & $-3,33$ & 20,00 \\
\hline 40 & (TURI) & 675 & 690 & 710 & 1.240 & 2,22 & 2,90 & 74,65 \\
\hline 41 & (UNIC) & 2.525 & 2.875 & 2.725 & 2.800 & 13,86 & $-5,22$ & 2,75 \\
\hline 42 & (UNVR) & 3.300 & 4.275 & 6.600 & 6.750 & 29,55 & 54,39 & 2,27 \\
\hline
\end{tabular}

Sumber: Data Sekunder (diolah)

Dari harga saham dalam tabel diatas dapat dilihat bahwa harga saham tertinggi yaitu 48.000 pada tahun 2004, 63.000 pada tahun 2005, 110.000 pada tahun 2006 dan 129.500 pada tahun 2007 yang dimiliki oleh PT. Aqua Golden Mississippi Tbk yang bergerak dalam bidang usaha Beverages (Bottled Mineral Water). Sedangkan harga saham terendah yaitu 60 pada tahun 2004, 45 pada tahun 2005, 50 pada tahun 2006 dan 81 pada tahun 2007 yang dimiliki oleh PT. Pyridam Farma Tbk yang bergerak dalam bidang usaha Pharmaceuticals. Berdasarkan tabel 4.4 dapat dilihat bahwa dari 42 sampel perusahaan manufaktur, terdapat 17 perusahaan manufaktur (ALMI, AQUA, BRAN, RMBA, CTBN, DVLA, FASW, FAST, INTP, INDF, MERCK, MLBI, RDTX, SMSM, STI, TURI dan UNVCR) mengalami kenaikan harga saham yang terus menerus dari tahun 2004 ke tahun 2005, tahun 2005 ke tahun 2006, tahun 2006 ke tahun 2007. Sementara 25 perusahaan manufaktur yang tersisa mengalami harga saham yang naik turun dari tahun 2004 ke tahun 2005, tahun 2005 ke tahun 2006 dan tahun 2006 ke tahun 2007.

\section{Data Variabel Independen}

Dalam penelitian ini variabel independen merupakan kinerja keuangan yang meliputi Quick Ratio (QR), Total Assets Turnover (TAT), Debt to Equity Ratio (DER), 
Return On Asset (ROA), dan Price Earning Ratio (PER). Berikut ini adalah data kinerja keuangan selama tahun 2005, 2006 dan 2007 dapat dilihat dalam tabel berikut ini. 
TABEL 5

Data QR, TAT, DER, ROA, PER Tahun 2005, 2006 dan 2007

\begin{tabular}{|c|c|c|c|c|c|c|c|c|c|c|c|c|c|c|c|c|}
\hline \multirow{2}{*}{ No } & \multirow{2}{*}{ Kode } & \multicolumn{3}{|c|}{ QR (X) } & \multicolumn{3}{|c|}{ TAT $(\mathbf{X})$} & \multicolumn{3}{|c|}{$\operatorname{DER}(\mathrm{X})$} & \multicolumn{3}{|c|}{ ROA (\%) } & \multicolumn{3}{|c|}{ PER (X) } \\
\hline & & 2005 & 2006 & 2007 & 2005 & 2006 & 2007 & 2005 & 2006 & 2007 & 2005 & 2006 & 2007 & 2005 & 2006 & 2007 \\
\hline 1 & (ALMI) & 0,50 & 0,49 & 0,46 & 1,69 & 1,58 & 1,69 & 1,10 & 1,74 & 2,07 & 4,64 & 6,66 & 2,31 & 2,76 & 3,18 & 9,22 \\
\hline 2 & (AQUA) & 6,71 & 6,86 & 6,78 & 2,13 & 2,12 & 2,19 & 0,78 & 0,77 & 0,74 & 8,79 & 6,14 & 7,39 & 12,89 & 29,64 & 25,86 \\
\hline 3 & (AKPI) & 0,96 & 1,14 & 0,84 & 0,72 & 0,80 & 0,87 & 1,41 & 1,36 & 1,32 & 0,77 & 1,00 & 1,48 & 31,36 & 23,32 & 13,64 \\
\hline 4 & (ASGR) & 2,45 & 1,80 & 0,92 & 1,05 & 1,06 & 1,16 & 0,82 & 0,98 & 0,99 & 6,95 & 9,50 & 11,54 & 11,03 & 7,40 & 11,04 \\
\hline 5 & (RMBA) & 1,25 & 0,81 & 1,22 & 1,18 & 1,28 & 1,19 & 0,65 & 0,97 & 1,50 & 5,87 & 6,20 & 6,29 & 8,40 & 14,34 & 15,52 \\
\hline 6 & $(\mathrm{BTON})$ & 3,76 & 1,90 & 2,58 & 1,96 & 1,70 & 2,48 & 0,12 & 0,31 & 0,35 & 6,31 & 2,43 & 18,90 & 20,57 & 44,01 & 3,79 \\
\hline 7 & (BRAM) & 1,61 & 2,30 & 3,35 & 1,03 & 0,99 & 1,00 & 0,87 & 0,61 & 0,52 & 6,99 & 1,20 & 2,52 & 3,54 & 46,69 & 21,84 \\
\hline 8 & (SQBI) & 1,89 & 1,98 & 2,00 & 1,01 & 1,17 & 1,14 & 0,63 & 0,59 & 0,43 & 5,48 & 20,84 & 22,94 & 11,88 & 12,29 & 1,96 \\
\hline 9 & $(\mathrm{CTBN})$ & 1,31 & 0,92 & 1,21 & 1,13 & 1,56 & 1,64 & 0,70 & 1,13 & 0,87 & 6,91 & 13,36 & 13,71 & 9,25 & 6,44 & 10,93 \\
\hline 10 & (DVLA) & 2,89 & 3,93 & 4,46 & 0,98 & 1,03 & 0,91 & 0,41 & 0,35 & 0,21 & 13,00 & 9,42 & 8,90 & 5,87 & 16,10 & 17,95 \\
\hline 11 & (DLTA) & 3,24 & 3,39 & 3,90 & 0,80 & 0,69 & 0,74 & 0,32 & 0,32 & 0,29 & 10,49 & 7,58 & 7,99 & 10,22 & 8,43 & 5,41 \\
\hline 12 & (FASW) & 0,92 & 0,83 & 1,19 & 0,52 & 0,49 & 0,70 & 1,69 & 1,91 & 1,91 & 0,20 & 2,97 & 3,24 & 425,17 & 28,01 & 36,16 \\
\hline 13 & $(\mathrm{FAST})$ & 0,83 & 0,76 & 0,99 & 2,72 & 2,64 & 2,53 & 0,66 & 0,68 & 0,67 & 10,93 & 14,25 & 16,29 & 12,97 & 11,78 & 10,66 \\
\hline 14 & (GJTL) & 1,41 & 1,09 & 1,61 & 0,65 & 0,75 & 0,79 & 2,68 & 2,41 & 2,54 & 4,64 & 1,63 & 1,07 & 5,12 & 15,52 & 17,09 \\
\hline 15 & (GGRM) & 0,31 & 0,40 & 0,42 & 1,12 & 1,21 & 1,18 & 0,69 & 0,65 & 0,69 & 8,54 & 4,64 & 6,03 & 11,86 & 19,47 & 11,33 \\
\hline 16 & (INTP) & 1,45 & 0,97 & 1,65 & 0,53 & 0,66 & 0,73 & 0,87 & 0,59 & 0,44 & 7,02 & 6,18 & 9,81 & 17,67 & 35,71 & 30,73 \\
\hline 17 & (INAF) & 1,11 & 1,14 & 1,01 & 1,32 & 1,49 & 1,26 & 0,96 & 1,45 & 2,46 & 1,85 & 2,22 & 1,10 & 37,15 & 20,34 & 57,36 \\
\hline 18 & (INDF) & 0,86 & 0,71 & 0,59 & 1,27 & 1,35 & 0,94 & 2,33 & 2,10 & 2,62 & 0,84 & 4,06 & 3,32 & 69,30 & 19,28 & 24,81 \\
\hline 19 & (INDR) & 1,03 & 0,81 & 0,77 & 0,84 & 0,79 & 0,81 & 1,38 & 1,51 & 1,62 & 0,37 & 0,34 & 0,37 & 15,07 & 17,17 & 22,65 \\
\hline 20 & (JPRS) & 3,21 & 25,31 & 3,69 & 1,84 & 1,80 & 1,61 & 0,25 & 0,06 & 0,22 & 16,63 & 14,15 & 15,46 & 3,52 & 44,50 & 6,41 \\
\hline 21 & (IGAR) & 2,32 & 2,40 & 2,20 & 1,60 & 1,42 & 1,42 & 0,42 & 0,44 & 0,53 & 5,01 & 3,43 & 4,68 & 8,00 & 10,01 & 8,10 \\
\hline 22 & (KAEF) & 1,45 & 1,50 & 1,36 & 1,54 & 1,74 & 1,71 & 0,39 & 0,45 & 0,53 & 4,49 & 3,49 & 3,76 & 15,24 & 20,83 & 32,46 \\
\hline
\end{tabular}

Sumber : Indonesian Capital Market Directory 2008

Terhadap Perubahan Harga SahamAnalisis Pengaruh Kinerja Keuangan Perusahaan 
TABEL 6

Data QR, TAT, DER, ROA, PER Tahun 2005, 2006 dan 2007 (lanjutan)

\begin{tabular}{|c|c|c|c|c|c|c|c|c|c|c|c|c|c|c|c|c|}
\hline \multirow{2}{*}{ No } & \multirow{2}{*}{ Kode } & \multicolumn{3}{|c|}{ QR (X) } & \multicolumn{3}{|c|}{ TAT $(X)$} & \multicolumn{3}{|c|}{$\operatorname{DER}(\mathbf{X})$} & \multicolumn{3}{|c|}{ ROA (\%) } & \multicolumn{3}{|c|}{$\operatorname{PER}(X)$} \\
\hline & & 2005 & 2006 & 2007 & 2005 & 2006 & 2007 & 2005 & 2006 & 2007 & 2005 & 2006 & 2007 & 2005 & 2006 & 2007 \\
\hline 23 & (LTLS) & 0,75 & 0,72 & 0,54 & 1,35 & 1,32 & 1,27 & 2,10 & 2,43 & 2,42 & 3,26 & 1,62 & 3,36 & 7,14 & 10,64 & 4,79 \\
\hline 24 & (LMSH) & 1,03 & 0,98 & 0,83 & 2,47 & 1,82 & 1,87 & 0,99 & 0,86 & 1,16 & 9,74 & 6,12 & 9,46 & 4,44 & 6,12 & 3,39 \\
\hline 25 & $(\mathrm{LION})$ & 3,49 & 3,77 & 3,37 & 0,78 & 0,76 & 0,83 & 0,23 & 0,25 & 0,27 & 11,53 & 11,00 & 11,71 & 5,47 & 5,54 & 4,32 \\
\hline 26 & (MYOR) & 2,64 & 2,78 & 2,18 & 1,17 & 1,27 & 1,49 & 0,61 & 0,58 & 0,73 & 3,13 & 6,02 & 7,48 & 13,75 & 13,27 & 9,47 \\
\hline 27 & (MERK) & 2,77 & 3,85 & 4,38 & 1,77 & 1,72 & 1,65 & 0,21 & 0,20 & 0,18 & 26,46 & 30,61 & 27,03 & 9,43 & 10,35 & 13,14 \\
\hline 28 & (MLBI) & 0,45 & 0,33 & 0,42 & 1,48 & 1,46 & 1,57 & 1,52 & 2,08 & 2,14 & 15,12 & 12,05 & 13,57 & 12,11 & 15,75 & 13,73 \\
\hline 29 & (MRAT) & 5,63 & 7,41 & 6,10 & 0,72 & 0,78 & 0,80 & 0,14 & 0,10 & 0,13 & 2,93 & 3,12 & 3,52 & 13,58 & 15,06 & 11,34 \\
\hline 30 & (PYFA) & 0,79 & 1,03 & 0,92 & 0,52 & 0,74 & 0,91 & 0,21 & 0,27 & 0,42 & 1,73 & 2,08 & 1,83 & 18,13 & 15,47 & 24,86 \\
\hline 31 & (RDTX) & 0,64 & 0,54 & 0,57 & 0,43 & 0,26 & 0,24 & 0,24 & 0,57 & 0,56 & 5,79 & 6,48 & 5,97 & 10,56 & 7,39 & 10,11 \\
\hline 32 & (BATA) & 0,77 & 1,03 & 1,07 & 1,30 & 1,23 & 1,28 & 0,55 & 0,53 & 0,66 & 9,91 & 9,23 & 9,68 & 6,03 & 7,61 & 7,71 \\
\hline 33 & (STTP) & 1,26 & 1,51 & 0,80 & 1,42 & 1,58 & 1,49 & 0,73 & 0,43 & 0,60 & 8,20 & 7,43 & 10,41 & 7,51 & 9,03 & 8,65 \\
\hline 34 & (SIMA) & 1,58 & 1,90 & 0,36 & 1,34 & 1,19 & 1,16 & 0,45 & 0,36 & 0,44 & 2,23 & 3,09 & 3,01 & 18,47 & 19,07 & 31,08 \\
\hline 35 & (IKBI) & 1,32 & 1,32 & 2,37 & 1,37 & 1,33 & 1,07 & 0,53 & 0,57 & 0,92 & 3,38 & 1,59 & 5,88 & 6,92 & 14,84 & 4,59 \\
\hline 36 & $(\mathrm{SMSM})$ & 1,12 & 1,09 & 0,83 & 2,60 & 3,24 & 2,70 & 0,62 & 0,58 & 0,34 & 4,33 & 7,52 & 13,15 & 5,54 & 5,65 & 4,54 \\
\hline 37 & $(\mathrm{STI})$ & 0,69 & 0,74 & 0,73 & 0,84 & 0,91 & 0,98 & 2,93 & 2,24 & 1,88 & 7,42 & 8,78 & 6,17 & 4,73 & 4,10 & 7,03 \\
\hline 38 & (AISA) & 0,52 & 0,61 & 0,39 & 0,64 & 0,92 & 0,97 & 2,76 & 2,82 & 3,65 & 0,01 & 0,04 & 3,06 & $6.491,88$ & $1.406,75$ & 49,68 \\
\hline 39 & (TRST) & 0,62 & 0,56 & 0,62 & 0,51 & 0,60 & 0,70 & 1,20 & 1,07 & 1,18 & 0,78 & 1,28 & 0,83 & 25,64 & 15,69 & 27,53 \\
\hline 40 & (TURI) & 1,01 & 1,03 & 1,04 & 1,53 & 1,36 & 1,32 & 3,44 & 3,24 & 2,91 & 4,74 & 0,78 & 5,67 & 6,74 & 44,59 & 9,11 \\
\hline 41 & (UNIC) & 0,91 & 0,72 & 0,55 & 1,09 & 1,06 & 1,14 & 1,22 & 1,43 & 1,13 & 1,81 & 0,41 & 1,27 & 22,64 & 92,61 & 32,33 \\
\hline 42 & (UNVR) & 0,84 & 0,89 & 0,76 & 2,60 & 2,45 & 2,35 & 0,76 & 0,95 & 0,98 & 37,49 & 37,22 & 36,79 & 22,64 & 29,25 & 26,25 \\
\hline
\end{tabular}

Sumber : Indonesian Capital Market Directory 2008 


\section{Analisis Data Penelitian}

\section{Statistik Deskriptif}

Deskripsi atas variabel penelitian dilakukan untuk mengetahui gambaran tentang variabel-variabel yang digunakan, yaitu dengan menjelaskan mengenai nilai minimum, nilai maksimum serta nilai rata-rata setiap variabel. Deskripsi variabel yang digunakan dalam penelitian ini dapat dilihat pada tabel 8 berikut ini

TABEL 7

Statistik Deskriptif

\begin{tabular}{|l|r|r|r|r|r|}
\hline & \multicolumn{1}{|c|}{ Descriptive Statistics } \\
\hline Perubahan Harga Saham & N & \multicolumn{1}{|c|}{ Minimum } & \multicolumn{1}{c|}{ Maximum } & \multicolumn{1}{c|}{ Mean } & Std. Deviation \\
QR & 85 & -.50 & 6.06 & 3.1071 & 1.29940 \\
TAT & 85 & -1.11 & 3.23 & .2334 & .78986 \\
DER & 85 & -1.43 & 1.18 & .1773 & .49234 \\
ROA & 85 & -2.81 & 1.29 & -.2354 & .85521 \\
PER & 85 & -4.61 & 3.62 & 1.6273 & 1.25797 \\
Valid N (listwise) & 85 & 1.16 & 8.78 & 2.7111 & 1.04747 \\
\hline
\end{tabular}

Sumber : Data sekunder yang diolah

Berdasarkan tabel diatas dapat dilihat bahwa nilai rata-rata perubahan harga saham sebesar 3,1071 dengan standar deviasi 1,29940 Perubahan harga saham minimum sebesar $-0,50$ dan maksimum sebesar 6,06. Nilai perubahan saham terendah dimiliki oleh PT. Roda Vivatex Tbk, sedangkan nilai perubahan saham terbesar dimiliki oleh PT. Bristol Myers Squibb Indonesia Tbk.

Rata-rata Quick Ratio sebesar 0,2334 dengan standar deviasi sebesar 0,78986. Nilai minimum quick ratio sebesar $-1,11$ dimiliki oleh PT. Multi Bintang Indonesia Tbk, sedangkan nilai maksimum sebesar 3,23 dimiliki oleh PT. Jaya Pari Steel Tbk.

Rata-rata Total assets turnover sebesar 0,1773 dengan standar deviasi sebesar 0,49234. Nilai minimum total assets turnover sebesar -1,43 dimiliki oleh PT. Roda Vivatex Tbk sedangkan nilai maksimum sebesar 1,18 dimiliki oleh PT. Sumi Indo Kabel Tbk.

Rata-rata dept to equity ratio sebesar -0,2354 dengan standar deviasi sebesar 0,85521. Nilai minimum dept to equity ratio sebesar $-2,81$ dimiliki oleh PT. Jaya Pari Steel Tbk dan nilai maksimum sebesar 1,29 dimiliki oleh PT. Tiga Pilar Sejahtera Food Tbk.

Rata-rata Return on Assets sebesar 1,6273 dengan standar deviasi sebesar 1,25797. Nilai minimum return on assets sebesar $-4,61$ dimiliki oleh PT. Tiga Pilar Sejahtera Food Tbk, sedangkan nilai maksmimum sebesar 3,62 dimiliki oleh PT. Unilever Indonesia Tbk.

Rata-rata Price Earning Ratio sebesar 2,7111 dengan standar deviasi sebesar 1,04747. Nilai minimum price earning ratio sebesar 1,16 dimiliki oleh 
PT. Alumindo Light Metal Industri Tbk, sedangkan nilai maksimum sebesar 8,78 dimiliki oleh PT. Tiga Pilar Sejahtera Food Tbk.

a. Uji Normalitas

Uji normalitas dilakukan untuk menguji apakah dalam sebuah model regresi, variabel independen, variabel dependen atau keduanya mempunyai distribusi normal. Model regresi yang baik adalah mempunyai distribusi normal.

Deteksi dengan melihat penyebaran data (titik) pada sumbu diagonal dari grafik dengan dasar pengambilan keputusan:

- Jika data menyebar di sekitar garis diagonal dan mengikuti arah garis diagonal, maka model regresi memenuhi asumsi normalitas.

- Jika data menyebar jauh dari garis diagonal dan tidak mengikuti arah garis diagonal, maka model regresi tidak memenuhi asumsi normalitas.

Berdasarkan hasil pengolahan SPSS 13.0 for Windows, didapat kurva pengujian normalitas variabel sebagai berikut :

Normal P-P Plot of Regression Standardized Residual

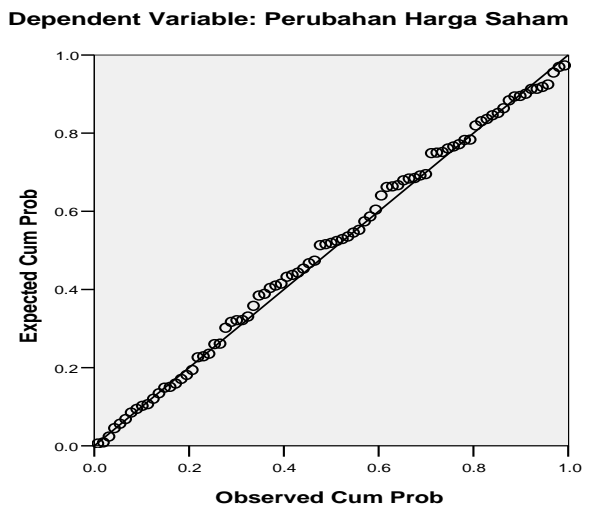

GAMBAR 2

Normal Probability Plot Pengujian Regresi

Pada gambar grafik di atas menunjukkan bahwa data menyebar di sekitar garis diagonal pada model regresi sehingga keseluruhan variabel independen terhadap variabel dependen menunjukkan adanya normalitas.

b. Uji Heteroskedastisitas

Uji heteroskedastisitas dilakukan untuk menguji apakah dalam sebuah regresi terjadi ketidaksamaaan varians dari residual dari satu pengamatan ke pengamatan yang lain. Model regresi yang baik adalah non heteroskedastis. Dasar pengambilan keputusan adalah dengan melihat ada tidaknya pola tertentu antara $\mathrm{Y}$ yang diprediksi dan residual.

- Jika ada pola tertentu seperti titik-titik yang ada membentuk suatu pola tertentu yang teratur maka terjadi heteroskedastis.

- Jika tidak ada pola yang jelas serta titik-titik menyebar di atas dan di bawah angka 0 , maka tidak terjadi heteroskedastis.

Berdasarkan hasil pengolahan SPSS 13.0 for Windows, didapatkan kurva pengujian heteroskedastisitas. 


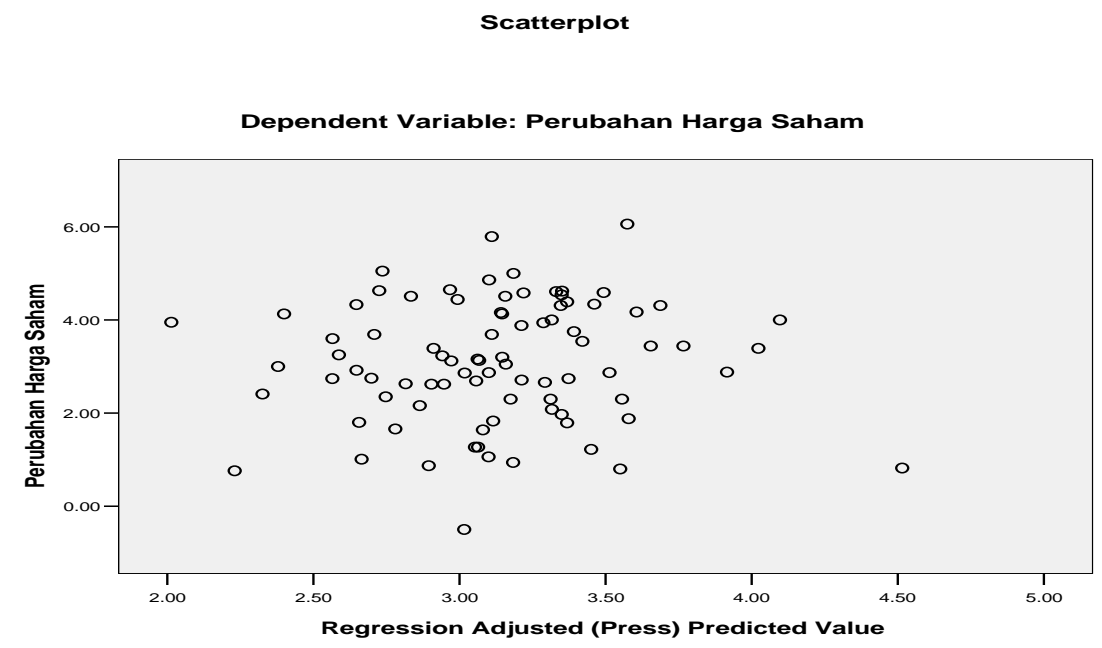

\section{GAMBAR 3 \\ Grafik Scatterplot Pengujian Heterokedastisitas}

Dari hasil gambar grafik antara nilai sumbu $\mathrm{Y}$ (nilai $\mathrm{Y}$ yang diprediksi) dan sumbu $X$ (nilai residual) menunjukkan pola yang tidak jelas serta titik menyebar di atas dan di bawah sumbu $\mathrm{Y}$ secara tidak teratur sehingga menunjukkan tidak terjadinya heteroskedastisitas

c. Uji Multikolinearitas

Uji multikolinearitas dilakukan untuk menguji apakah pada model regresi ditemukan adanya korelasi antar variabel bebas. Model regresi yang baik adalah non multikolinear. Analisis ini ditentukan oleh besarnya nilai VIF (Varians Inflation Factor) dan Tolerance. Pedoman suatu model regresi yang bebas multikolinearitas adalah mempunyai nilai VIF tidak lebih dari 10 dan mempunyai angka tolerance tidak kurang dari 0,1 .

TABEL 8

Hasil Uji Multikolinearitas

Coefficients $^{\mathrm{a}}$

\begin{tabular}{|c|c|c|}
\hline \multirow{2}{*}{$\begin{array}{c}\text { Variabel } \\
\text { (constant) }\end{array}$} & \multicolumn{2}{|c|}{ Collinearity Statistics } \\
\cline { 2 - 3 } & Tolerance & VIF \\
\hline QR & 0.488 & 2.049 \\
TAT & 0.770 & 1.299 \\
DER & 0.439 & 2.279 \\
ROA & 0.386 & 2.588 \\
PER & 0.518 & 1.931 \\
\hline
\end{tabular}

a. Dependent Variable: (Y)Perubahan Harga Saham

Sumber: Hasil olahan dari SPSS 13.0 for Windows 
Berdasarkan tabel di atas dapat diketahui bahwa besarnya seluruh nilai VIF (Varians Inflation Factor) dari masing-masing variabel independen memiliki nilai VIF tidak lebih dari 10 dan tolerance tidak kurang dari 0,1 . Semakin tinggi nilai VIF maka semakin rendah nilai tolerance sehingga dapat disimpulkan bahwa seluruh variabel tidak menunjukkan adanya multikolinearitas.

\section{Analisis Regresi Berganda}

Suatu persamaan regresi harus memiliki data yang terdistribusi normal, bebas dari heterokedastisitas, dan tidak terjadi multikolinearitas agar diperoleh persamaan regresi yang baik dan tidak bias. Berdasarkan hasil uji asumsi klasik dapat diketahui bahwa data yang digunakan dalam persamaan terdistribusi normal, bebas heterokedastisitas, dan tidak terjadi multikolinearitas, sehingga memenuhi syarat untuk melakukan analisis regresi yang baik.

Pengujian dilakukan untuk mengetahui hubungan antara variabel-variabel Quick Ratio(QR), Total Assets Turnover (TAT), Debt to Equity Ratio (DER), Return On Asset (ROA), dan Price Earning Ratio (PER) terhadap perubahan harga saham pada perusahaan manufaktur yang terdaftar di BEI, sehingga dapat dihitung dengan menggunakan model regresi linier berganda (multiple regression). Berdasarkan perhitungan regresi dengan menggunakan program SPSS 13.0 for Windows maka diperoleh hasil sebagai berikut :

TABEL 9

Hasil Analisis Regresi Berganda

\begin{tabular}{|c|c|c|c|c|c|c|c|c|c|c|c|}
\hline \multicolumn{12}{|c|}{ Coefficients ${ }^{a}$} \\
\hline \multirow[b]{2}{*}{ Mode } & & \multicolumn{2}{|c|}{$\begin{array}{l}\text { Unstandardized } \\
\text { Coefficients }\end{array}$} & \multirow{2}{*}{$\begin{array}{c}\text { Standardized } \\
\text { Coeff icients } \\
\text { Beta }\end{array}$} & \multirow[b]{2}{*}{ t } & \multirow[b]{2}{*}{ Sig. } & \multicolumn{3}{|c|}{ Correlations } & \multicolumn{2}{|c|}{ Collinearity Statistics } \\
\hline & & $B$ & Std. Error & & & & Zero-order & Partial & Part & Tolerance & VIF \\
\hline 1 & (Constant) & 1.832 & .711 & & 2.578 & .012 & & & & & \\
\hline & $Q R$ & .251 & .251 & .152 & .998 & .321 & .117 & .112 & .106 & .488 & 2.049 \\
\hline & TAT & .020 & .321 & .007 & .061 & .951 & .156 & .007 & .007 & .770 & 1.299 \\
\hline & DER & .316 & 244 & .208 & 1.291 & .200 & -.035 & .144 & .138 & .439 & 2.279 \\
\hline & ROA & .424 & .177 & .411 & 2.395 & .019 & .250 & .260 & .255 & .386 & 2.588 \\
\hline & PER & .220 & .184 & .177 & 1.198 & .234 & -.068 & .134 & .128 & .518 & 1.931 \\
\hline
\end{tabular}

a. Dependent Variable: Perubahan Harga Saham

Berdasarkan tabel tersebut diatas analisis regresi berganda yang dihasilkan dengan bantuan SPSS 13.0 for Windows, diperoleh persamaan regresinya sebagai berikut :

$$
Y=1,832+0,251 X_{1}+0,20 X_{2}+0,316 X_{3}+0424 X_{4}+0,220 X_{5}
$$

Dari hasil persamaan yang telah disusun di atas dapat diuraikan pengertian nilai-nilai koefisien regresi sebagai berikut:

a. Konstanta $\alpha=1,832$ menunjukkan bahwa apabila variabel $\mathrm{QR}$ $\left(\mathrm{X}_{1}\right)$, variabel TAT $\left(\mathrm{X}_{2}\right)$, variabel DER $\left(\mathrm{X}_{3}\right)$, variabel ROA $\left(\mathrm{X}_{4}\right)$, dan variabel PER $\left(\mathrm{X}_{5}\right)$ sama dengan nol, maka nilai harga saham adalah $1,832 \%$.

b. Koefisien $\beta_{1}=0,251$ menunjukkan bahwa variabel quick ratio $\left(\mathrm{X}_{1}\right)$ mempunyai pengaruh positif dengan harga saham (Y). Apabila variabel 
independen lainnya tetap, maka setiap kenaikan quick ratio sebesar $1 \%$ akan mengakibatkan kenaikan harga saham sebesar 0,251\%.

c. Koefisien $\beta_{2}=0,20$ menunjukkan bahwa variabel TAT $\left(\mathrm{X}_{2}\right)$ mempunyai pengaruh positif dengan harga saham (Y). Apabila variabel independen lainnya tetap, maka setiap peningkatan total assets turnover sebesar $1 \%$ akan mengakibatkan kenaikan harga saham sebesar 0,20\%.

d. Koefisien $\beta_{3}=0,316$ menunjukkan bahwa variabel DER $\left(X_{3}\right)$ mempunyai pengaruh positif dengan harga saham (Y). Apabila variabel independen lainnya tetap, maka setiap kenaikan debt to equity ratio sebesar $1 \%$ akan mengakibatkan kenaikan harga saham sebesar 0,316\%.

e. Koefisien $\beta_{4}=0,424$ menunjukkan bahwa variabel ROA $\left(\mathrm{X}_{4}\right)$ mempunyai pengaruh positif dengan harga saham (Y). Apabila variabel independen lainnya tetap, maka setiap kenaikan return on assets sebesar $1 \%$ akan mengakibatkan kenaikan harga saham sebesar $0,424 \%$.

f. Koefisien $\beta_{5}=0,220$ menunjukkan bahwa variabel PER $\left(\mathrm{X}_{5}\right)$ mempunyai pengaruh positif dengan harga saham (Y). Apabila variabel independen lainnya tetap, maka setiap kenaikan price earning ratio sebesar 1\% akan mengakibatkan kenaikan harga saham sebesar 0,220\%.

\section{Pengujian Hipotesis}

a. Pengujian hipotesis pertama

Dari hasil pengolahan data diperoleh nilai $t_{\text {hitung }}$ sebesar 0,998 lebih kecil dari nilai $t_{\text {tabel }}$ sebesar 1,990 serta nilai probabilitas sebesar 0,321 lebih besar dari tingkat signifikansi $(\alpha)$ sebesar 0,05 , maka dapat disimpulkan $\mathrm{H}_{0}$ diterima dan Ha ditolak, artinya quick ratio secara parsial tidak berpengaruh signifikan terhadap perubahan harga saham. Sehingga dapat disimpulkan bahwa hipotesis 1 ditolak.

b. Pengujian hipotesis kedua

Dari hasil pengolahan data diperoleh nilai $t_{\text {hitung }}$ sebesar 0,061 lebih kecil dari nilai $t_{\text {tabel }}$ sebesar 1,990 serta nilai probabilitas sebesar 0,951 lebih besar dari tingkat signifikansi 0,05, maka dapat disimpulkan bahwa $\mathrm{H}_{0}$ diterima dan $\mathrm{Ha}$ ditolak, artinya total assets turnover secara parsial tidak berpengaruh signifikan terhadap perubahan harga saham. Sehingga dapat disimpulkan bahwa hipotesis 2 ditolak.

\section{c. Pengujian hipotesis ketiga}

Karena nilai $t_{\text {hitung }}$ sebesar 1,291 lebih kecil dari nilai $t_{\text {tabel }} 1,990$ serta nilai probabilitas sebesar 0,200 lebih besar dari tingkat signifikansi sebesar 0,05, maka dapat disimpulkan $\mathrm{H}_{0}$ diterima dan $\mathrm{Ha}$ ditolak, artinya debt to equity ratio secara parsial tidak berpengaruh signifikan terhadap perubahan harga saham. Sehingga dapat disimpulkan bahwa hipotesis 3 ditolak.

d. Pengujian hipotesis keempat 
Karena nilai $t_{\text {hitung }}$ sebesar 2,395 lebih besar dari nilai $t_{\text {tabel }} 1,990$ dan nilai probabilitas sebesar 0,019 lebih kecil dari tingkat signifikansi sebesar 0,05, maka dapat disimpulkan bahwa $\mathrm{H}_{0}$ ditolak dan Ha diterima, artinya return on assets secara parsial berpengaruh signifikan terhadap perubahan harga saham. Sehingga dapat disimpulkan bahwa hipotesis 4 diterima.

e. Pengujian hipotesis kelima

Karena nilai $t_{\text {hitung }}$ sebesar 1,198 lebih kecil dari nilai $t_{\text {tabel }} 1,990$ serta nilai probabilitas sebesar 0,234 lebih besar dari tingkat signifikansi sebesar 0,05, maka dapat disimpulkan Ho diterima dan Ha ditolak, artinya price earning ratio secara parsial tidak berpengaruh signifikan terhadap perubahan harga saham. Sehingga dapat disimpulkan bahwa hipotesis 5 ditolak.

\section{f. Pengujian hipotesis keenam}

Karena $F_{\text {hitung }}$ sebesar 1,806 lebih kecil dari $F_{\text {tabel }}$ sebesar 2,330 serta nilai probabilitas variabel independen sebesar 0,121 lebih besar dari tingkat signifikansi $(\alpha)$ sebesar 0,05 , maka dapat disimpulkan $\mathrm{H}_{0}$ diterima dan $\mathrm{Ha}$ ditolak, artinya Quick ratio, total assets turnover, debt to equity ratio, return on assets, dan price earning ratio secara simultan tidak berpengaruh signifikan terhadap perubahan harga saham pada perusahaan manufaktur yang terdaftar di Bursa Efek Indonesia. Sehingga dapat disimpulkan bahwa hipotesis 6 ditolak, artinya kelima varibel (Quick ratio, total assets turnover, debt to equity ratio, return on assets, dan price earning ratio) tidak dapat digunakan untuk memprediksi perubahan harga saham.

\section{Analisis Koefisien Determinasi}

Besarnya pengaruh kinerja keuangan perusahaan (QR, TAT, DER, ROA, dan PER) secara simultan terhadap perubahan harga saham dapat dilihat pada tabel 10.

TABEL 10

\section{Hasil Pengujian Koefisien Determinasi}

Model Summary ${ }^{b}$

\begin{tabular}{|l|r|r|r|r|r|}
\hline Model & $\mathrm{R}$ & $\mathrm{R}$ Square & $\begin{array}{c}\text { Adjusted } \\
\text { R Square }\end{array}$ & $\begin{array}{r}\text { Std. Error of } \\
\text { the Estimate }\end{array}$ & $\begin{array}{r}\text { Durbin- } \\
\text { Watson }\end{array}$ \\
\hline 1 & $.320^{\mathrm{a}}$ & .103 & .046 & 1.26931 & 1.529 \\
\hline
\end{tabular}

a. Predictors: (Constant), PER, QR, TAT, DER, ROA

b. Dependent Variable: Perubahan Harga Saham

Dalam kolom Adjusted $R$ square sebesar 0,046 yang berarti 4,6\% dari perubahan harga saham bisa dijelaskan oleh variabel QR $\left(\mathrm{X}_{1}\right)$, TAT $\left(\mathrm{X}_{2}\right)$, DER 
$\left(\mathrm{X}_{3}\right)$, ROA $\left(\mathrm{X}_{4}\right)$, dan PER $\left(\mathrm{X}_{5}\right)$, sedangkan sisanya $95,4 \%$ dijelaskan oleh sebabsebab yang lain.

Berdasarkan hasil uji asumsi klasik, model regresi berganda memenuhi uji asumsi klasik yang terdiri dari uji normalitas, uji heteroskedastisitas dan uji multikolinearitas. Berdasarkan hasil analisis data secara statistik yang telah dilakukan terhadap 85 sampel perusahaan manufaktur periode 2005-2007 menunjukkan bahwa quick ratio, total assets turnover, debt to equity ratio, return on assets, dan price earning ratio secara simultan tidak berpengaruh signifikan terhadap perubahan harga saham. Dalam penelitian ini variabel harga saham hanya mampu dijelaskan oleh variabel kinerja keuangan perusahaan sebesar 4,6\%, artinya variabel perubahan harga saham sebesar 95,4\% dipengaruhi oleh faktor lain selain dari variabel perubahan kinerja keuangan perusahaan $(\mathrm{QR}, \mathrm{TAT}, \mathrm{DER}$, ROA, dan PER) yang tidak termasuk ke dalam model penelitian.

Kemungkinan perubahan harga saham juga dipengaruhi oleh peristiwa luar biasa, seperti krisis keuangan global di Amerika. Krisis keuangan global di Amerika Serikat disebabkan oleh subprime mortgage. Subprime mortgage adalah pemberian kredit pemilikan rumah oleh bank kepada konsumen yang dilakukan dengan tidak begitu memperhatikan kelayakan menerima kredit yang kemudian diinvestasikan oleh perbankan ke pasar modal. Cara lembaga perbankan menginvestasikan kredit pelanggan dengan memanipulasi kemacetan dari kredit hipotek tersebut dalam bentuk instrumen keuangan yang disebut derivatif. Instrumen keuangan ini digunakan untuk mengurangi risiko akibat pergerakan harga, tetapi kemudian dimanfaatkan lebih untuk berspekulasi. Pengaruh dari krisis keuangan global ini dirasakan sampai ke berbagai negara, termasuk Indonesia. Harga-harga saham di Bursa Efek Indonesia mengalami fluktuasi yang sangat tinggi dan terjadi transaksi short sale sehingga merugikan pihak emiten dan investor.

Selain itu, penilaian terhadap bursa saham di Indonesia dapat dilihat dari segi efisiensi pasar baik secara informasi maupun secara keputusan. Suatu pasar modal dikatakan efisien secara informasi dilihat dari ketersediaan jenis informasi yang digunakan, seperti informasi yang tidak dipublikasikan (privat) dan informasi yang dipublikasikan (Jogiyanto, 2008:492). Suatu pasar modal dikatakan efisien secara keputusan dilihat tidak hanya dari ketersediaan informasi, tetapi juga dilihat dari kecanggihan (sophisticated) pelaku pasar dalam mengolah informasi untuk pengambilan keputusan (Jogiyanto, 2008:499).

Untuk mendukung pemenuhan akan informasi para investor dalam pengambilan keputusan tentang harga saham, pada kenyataannya diperlukan analisis kinerja keuangan. Hal ini bertujuan agar setiap keputusan dalam berinvestasi para investor mempunyai landasan yang kuat dengan melihat kondisi perusahaan pada saat sekarang maupun di masa yang akan datang.

Harga saham selalu berfluktuasi mengikuti arah permintaan dan penawaran di pasar modal. Fluktuasi harga saham mencerminkan seberapa besar minat investor terhadap saham perusahaan. Jika pasar menilai kondisi perusahaan baik maka banyak investor yang tertarik untuk membeli saham perusahaan tersebut dan menyebabkan harga saham perusahaan mengalami kenaikan. Sebaliknya, jika kondisi perusahaan buruk maka harga saham perusahaan akan mengalami 
penurunan. Makin tinggi tingkat keuntungan perusahaan, makin tinggi pula nilai perusahaan yang diberikan oleh pihak investor.

Quick ratio merupakan rasio likuiditas yang membandingkan antara total aset lancar (setelah dikurangi oleh persediaan) dan total hutang lancar. Quick ratio menunjukkan seberapa likuid total asset perusahaan setelah dikurangi persediaan untuk menjamin total hutang lancar perusahaan. Hasil penelitian ini menunjukkan bahwa perubahan Quick ratio tidak berpengaruh signifikan terhadap perubahan harga saham. Quick ratio menghilangkan unsur persediaan. Padahal pada perusahaan manufaktur, persediaan merupakan aktiva yang paling penting karena digunakan untuk menjalankan kegiatan operasional perusahaan.

Total assets turnover merupakan rasio aktivitas yang menjelaskan efisiensi dana yang tertanam dalam keseluruhan aktiva rata-rata dalam satu tahun berputar $\mathrm{n}$ kali. Hasil penelitian ini menunjukkan bahwa perubahan total assets turnover tidak berpengaruh signifikan terhadap perubahan harga saham. Hal ini menunjukkan bahwa bagi investor perubahan total assets turnover bukan pertimbangan utama dalam melakukan investasi.

Perubahan debt to equity ratio tidak berpengaruh signifikan terhadap perubahan harga saham. Hal ini mungkin disebabkan investor tidak melihat berapa besar komposisi pendanaan dalam suatu perusahaan, tetapi investor lebih melihat efektivitas dari pendanaan tersebut untuk digunakan dalam aktivitas perusahaan untuk mendapatkan keuntungan. Hasil penelitian bertentangan dengan hasil penelitian yang dilakukan oleh Kusumasari (2005) yang menyatakan bahwa perubahan debt to equity ratio berpengaruh negatif dan signifikan terhadap harga saham.

Return on assets merupakan salah satu rasio profitabiltas yang diukur dari sisi perusahaan. ROA menunjukkan seberapa efektif aktiva yang digunakan perusahaan untuk menghasilkan laba. Hasil penelitian ini menunjukkan bahwa perubahan return on assets berpengaruh signifikan terhadap perubahan harga saham. Hasil penelitian ini mendukung penelitian yang dilakukan oleh Budiman (2007). Bagi para pemodal yang akan melakukan transaksi pembelian saham, penilaian terhadap kemampuan emiten dalam menghasilkan laba merupakan suatu hal yang sangat penting. Hal ini dikarenakan apabila laba suatu perusahaan meningkat, maka harga saham tersebut juga meningkat.

Price earning ratio menggambarkan besarnya perbandingan antara harga pasar saham per lembar dan Earning per Share (EPS) perusahaan. PER merupakan indikator yang dapat dipergunakan untuk menentukan apakah harga saham dinilai tinggi atau rendah. Hasil penelitian ini menunjukkan bahwa perubahan variabel price earing ratio tidak berpengaruh signifikan terhadap perubahan harga saham. Hal ini bertentangan dengan hasil penelitian yang dilakukan oleh Susilawati (2005) yang menyatakan bahwa price earning ratio mempunyai hubungan searah yang signifikan.

Pengaruh quick ratio, total assets turnover, debt to equity ratio dan return on assets yang tidak signifikan terhadap perubahan harga saham kemungkinan disebabkan oleh faktor eksternal perusahaan seperti kekuatan pasar, isu yang berkembang mengenai lingkungan sosial dan ekonomi, keamanan, politik, serta perbedaan karakteristik antara perusahaan yang digunakan oleh peneliti dengan perusahaan yang dijadikan obyek oleh para peneliti terdahulu (Kusumasari, 2005). Dengan demikian, dapat dikatakan bahwa perubahan harga saham tidak hanya 
dipengaruhi oleh faktor internal perusahaan, tetapi juga dipengaruhi oleh faktor eksternal seperti fluktuasi situasi pasar modal yang tidak menentu. 


\section{Simpulan}

Berdasarkan hasil analisis data mengenai pengaruh kinerja keuangan quick ratio, total assets turnover, debt to equity, return on asset, dan price earning ratio terhadap harga saham pada periode 2005-2007 dapat ditarik kesimpulan sebagai berikut:

1. Berdasarkan analisis regresi berganda maka diperoleh persamaan regresi sebagai berikut :

$Y=1,832+0,251 X_{1}+0,20 X_{2}+0,316 X_{3}+0424 X_{4}+0,220 X_{5}$

Dari persamaan regresi linier berganda tersebut, maka variabel quick ratio, debt to equity, total assets turnover, return on asset, dan price earning ratio berpengaruh positif dengan perubahan harga saham.

2. Berdasarkan hasil uji hipotesis parsial (uji t), maka dapat diperoleh hasil sebagai berikut :

a. Quick Ratio ( $Q R$ ) dengan perubahan harga saham menghasilkan nilai $t_{\text {hitung }}$ sebesar $0,998<$ nilai $t_{\text {tabel }}$ sebesar 1,990 sehingga secara parsial tidak berpengaruh signifikan terhadap perubahan harga saham. Dengan demikian hipotesis 1 ditolak.

b. Total Assets Turnover (TAT) dengan perubahan harga saham menghasilkan nilai $t_{\text {hitung }}$ sebesar $0,061<$ nilai $t_{\text {tabel }}$ sebesar 1,990 sehingga secara parsial tidak berpengaruh signifikan terhadap perubahan harga saham. Dengan demikian hipotesis 2 ditolak.

c. Debt to Equity Ratio (DER) dengan perubahan harga saham menghasilkan nilai $t_{\text {hitung }}$ sebesar 1,291 < nilai $t_{\text {tabel }}$ 1,990 sehingga secara parsial tidak berpengaruh signifikan terhadap perubahan harga saham. Dengan demikian hipotesis 3 ditolak.

d. Return On Asset (ROA) dengan perubahan harga saham menghasilkan nilai $t_{\text {hitung }}$ sebesar 2,395 > nilai $t_{\text {tabel }} 1,990$ sehingga secara parsial berpengaruh signifikan terhadap perubahan harga saham. Dengan demikian hipotesis 4 diterima.

e. Price Earning Ratio (PER) dengan perubahan harga saham menghasilkan nilai $t_{\text {hitung }}$ sebesar $1,198<$ nilai $t_{\text {tabel }} 1,990$ sehingga secara parsial tidak berpengaruh signifikan terhadap perubahan harga saham. Dengan demikian hipotesis 5 ditolak

3. Berdasarkan hasil uji hipotesis simultan (uji F), maka antara Quick Ratio(QR), Total Assets Turnover (TAT), Debt to Equity Ratio (DER), Return On Asset (ROA), dan Price Earning Ratio (PER) dengan perubahan harga saham menghasilkan nilai $F_{\text {hitung }}$ sebesar $1,806<$ nilai $F_{\text {tabel }}$ sebesar 2,330 sehingga secara simultan tidak berpengaruh signifikan terhadap perubahan harga saham. Dengan demikian hipotesis 6 ditolak, artinya kelima varibel (quick ratio, total assets turnover, debt to equity ratio, return on assets, dan price earning ratio) tidak dapat digunakan untuk memprediksi perubahan harga saham.

\section{Saran}

Dari analisis data yang telah dilakukan dan berdasarkan kesimpulan, penulis mencoba untuk memberikan saran sebagai berikut: 
1. Bagi investor dan calon investor

Dengan melihat nilai adjusted $R$ square sebesar 0,046 yang berarti bahwa 4,6\% varian yang terjadi pada perubahan harga saham disebabkan oleh kelima variabel independen yaitu quick ratio, total assets turnover, debt to equity, return on assets, dan price earning ratio sedangkan sisanya sebesar 95,4\% disebabkan oleh variabel atau faktor lain yang tidak termasuk dalam model penelitian. Hal ini menjadi perhatian para investor untuk tidak meletakkan kepercayaan pada struktur modal dan struktur finansial perusahaan dalam menilai suatu saham, masih diperlukan variabel-variabel fundamental seperti persediaan, piutang dagang, dan pengeluaran modal. Di samping itu juga diperlukan pengetahuan tentang tingkat kredibilitas perusahaan di lingkungan masyarakat yang dinilai dari likuiditas perusahaan, serta situasi pasar modal yang berfluktuasi dengan berbagai faktor lainnya, seperti pengumuman dan pembayaran dividen.

2. Bagi penelitian selanjutnya

Untuk mendapatkan hasil yang lebih baik, sebaiknya penelitian ini masih perlu diuji ulang dalam hal penggunaan jenis rasio keuangan, data harga saham, periode penelitian, dan jenis perusahaan yang berbeda karena jumlah sampel dan tahun yang berbeda tentu akan mendapatkan hasil interpretasi yang berbeda pula.

\section{Referensi}

2008. Indonesian Capital Market Directory. Jakarta: Institute for Economical and Financial Research.

. 2007. Tentang BEI: Sejarah. http://www.idx.co.id/ diakses pada tanggal

17 Desember 2009 pukul 15.35 WIB.

Arikunto, Suharsimi. 2006. Prosedur Penelitian Suatu Pendekatan Praktik. Edisi Revisi VI. Jakarta: Rineka Cipta.

Azwar, Saifudin. 2005. Metode Penelitian. Yogyakarta, Pustaka Pelajar.

Budiman, Ignatius Sarto Kothson. 2007. Analisis Hubungan Profitabilitas Dengan Harga Saham Sektor Usaha Makanan dan Minuman di Bursa Efek Jakarta. Journal The Winners. Vol. 8, No. 1. hal. 1-23.

Darmadji, Tjiptono dan Hendy M. Fakhruddin. 2006. Pasar Modal Di Indonesia Pendekatan Tanya Jawab. Jakarta: Salemba Empat.

Firdaus, Muhammad. 2004. Ekonometrika Suatu Pendekatan Aplikatif. Jakarta: PT Bumi Aksara.

Gujarati, Damodar. 1997. Ekonometrika Dasar. Jakarta, Erlangga. 
Hanafi, Mamduh M. dan Abdul Halim. 2005. Analisis Laporan Keuangan. Edisi Kedua. Yogyakarta: UPP AMP YKPN.

Hidayat, Herlin. 2000. Analisis Hubungan Kinerja Keuangan Dengan Harga Saham: Studi Kasus pada Perusahaan Makanan PT Sari Husada, PT Mayora Indah, PT Suba Indah, Dan Smart Corporation. Atma nan Jaya. Vol. April, No.1 Tahun XIII. hal. 73-92.

Ikatan Akuntansi Indonesia. 2004. Standar Akuntansi Keuangan. Jakarta: Salemba Empat.

Jogiyanto. 2008. Teori Portofolio dan Analisis Investasi. Edisi 3. Yogyakarta: BPFE.

Kieso, Donal E., Jerry J. Weygrandt, dan Terry D. Warfield. 2002. Intermediate Accounting. Tenth Edition. Jakarta: Penerbit Erlangga.

Kuncoro, Mudrajad. 2005. Strategi: Bagaimana Meraih Keunggulan Kompetitif. Yogyakarta: Penerbit Erlangga.

Kusumasari, Ratna. 2005. Pengaruh Kinerja Keuangan Perusahaan Terhadap Harga Saham. Skripsi S1 Fakultas Ekonomi Universitas Sanata Dharma: Yogyakarta.

Priyatno, Dwi. 2008. Mandiri Belajar SPSS untuk Analisis Data \& Uji Statistik. Yogyakarta, MediaKom.

Rosyadi, Imron. 2002. Keterkaitan Kinerja Keuangan Dengan Harga Saham. Jurnal Akuntansi dan Keuangan. Vol. 1, No. 1. hal. 24-48.

Rudianto. 2006. Akuntansi Manajemen: Informasi untuk Pengambilan Keputusan Manajemen. Jakarta: PT Gramedia Widiasarana Indonesia.

Salim, Lani. 2003. Analisa Teknikal Dalam Perdagangan Saham. Jakarta: PT Gramedia

Sulistyastuti, Dyah Ratih. 2002. Saham dan Obligasi: Ringkasan Teori dan Soal Jawab. Yogyakarta: Universitas Atma Jaya.

Susilawati, Christine Dwi Karya. 2005. Pengaruh Rasio Keuangan Terhadap Harga Saham Pada Perusahaan Manufaktur. Jurnal Ilmiah Akuntansi. Vol. 5, No. 2. hal. 55-75.

Sunariyah. 2006. Pengantar Pengetahuan Pasar Modal. UPP AMP YKPN. Yogyakarta.

Suwardjono. 2002. Akuntansi Pengantar. Yogyakarta: BPFE. 
Suwardjono. 2006. Teori Akuntansi: Perekayasaan Pelaporan Keuangan. Yogyakarta: BPFE.

Syahib Natarsyah. 1998. "Analisis Pengaruh Beberapa Faktor Fundamental dan Resiko Sistematik Terhadap Harga Saham". Jurnal Ekonomi dan Bisnis Indonesia. Vol 15, No. 3

Tandelilin, Eduardus. 2001. Analisis Investasi dan Manajemen Portofolio. Edisi I. Yogyakarta: BPFE. 